\title{
The Development of Chemically Vapor Deposited Mullite Coatings for the Corrosion Protection of SiC
}

May 1, 1998

Report Prepared by

Michael Auger, Ping Hou, Anita Sengupta, Somendra Basu, and Vinod Sarin

Boston University

Manufacturing Engineering

15 St. Mary's Street

Boston MA 02215

under

ORNL/Sub/94-SS110/04
RECEIVED

AUG 061998

OSTI

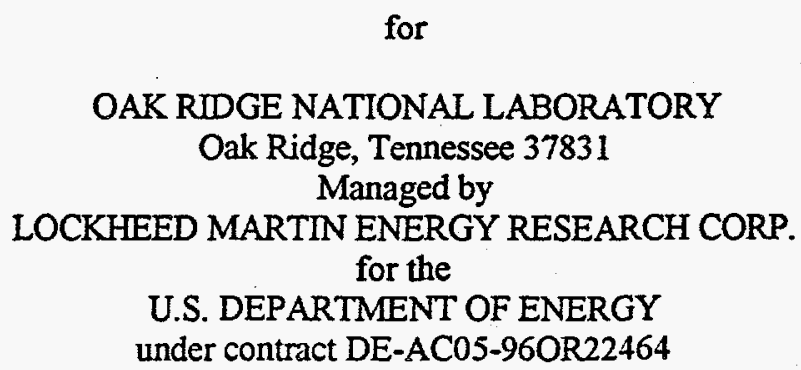

for

OAK RIDGE NATIONAL LABORATORY

Oak Ridge, Tennessee 37831

Managed by

LOCKHEED MARTIN ENERGY RESEARCH CORP.

for the

U.S. DEPARTMENT OF ENERGY

under contract DE-AC05-96OR22464

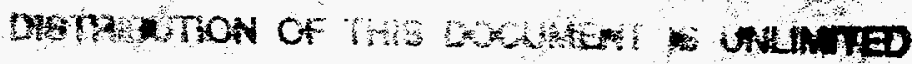




\section{DISCLAIMER}

Portions of this document may be illegible in electronic image products. Images are produced from the best available original document. 


\section{The Development of Chemically Vapor Deposited Mullite Coatings for the Corrosion Protection of SiC}

May 1, 1998

Research sponsored by the U.S. Department of Energy,

Office of Fossil Energy

Advanced Research and Technology Development Materials Program

Report Prepared by

Michael Auger, Ping Hou, Anita Sengupta, Somendra Basu, and Vinod Sarin

Boston University

Manufacturing Engineering

15 St. Mary's Street

Boston MA 02215

under

ORNL/Sub/94-SS110/04

for

OAK RIDGE NATIONAL LABORATORY

Oak Ridge, Tennessee 37831

Managed by

LOCKHEED MARTIN ENERGY RESEARCH CORP.

for the

U.S. DEPARTMENT OF ENERGY

under contract DE-AC05-96OR22464 
Research sponsored by the U.S. Department of Energy, Fossil Energy Advanced Research and Technology Development Materials Program, DOE/FE AA 151010 , Work Breakdown Structure Element BU-2

\begin{abstract}
Crystalline mullite coatings have been chemically vapor deposited onto SiC substrates to enhance the corrosion and axidation resistance of the substrate. Current research has been divided into three distinct areas: 1) Development of the depasition processing conditions for increased control over coating's growth rate, microstructure, and morphology, 2) Analysis of the coating's crystal structure and stability, 3) The corrosion resistance of the CVD mullite coating on $\mathrm{SiC}$
\end{abstract}

\title{
Contents
}

1 Introduction

2 Experimental Procedure

3 Results and Discussion

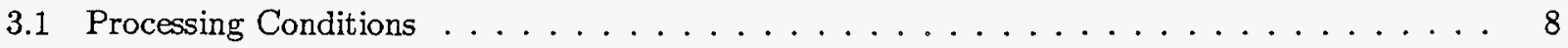

3.1 .1 Gas Velocity and Uniformity . . . . . . . . . . . . . 10

3.2 Microstructures of the CVD Mullite Coating $\ldots \ldots \ldots \ldots \ldots \ldots$

3.2 .1 Mullite Coating on SiC Substrate . . . . . . . . . . . . . . 17

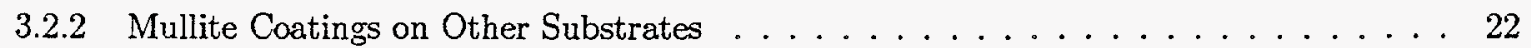

3.3 Post Exposure Coal Slag . . . . . . . . . . . . . . . . . . . . . . . . 22

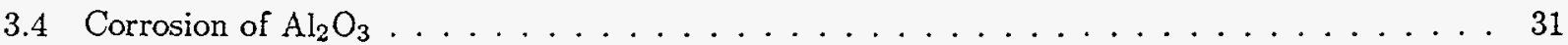

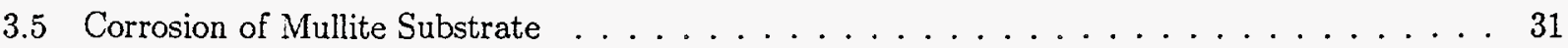

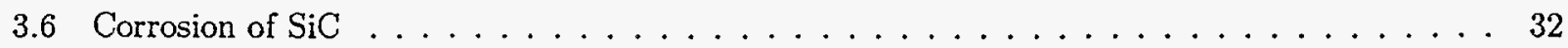

3.7 Corrosion of CVD Mullite Coated $\mathrm{SiC} \ldots \ldots \ldots \ldots \ldots \ldots \ldots \ldots$

4 Conclusions

5 Acknowledgments 


\section{List of Figures}

1 Growth Rate vs. Input $\mathrm{Al} / \mathrm{Si}$ without regard for metal chloride concentration $\ldots \ldots \ldots 11$

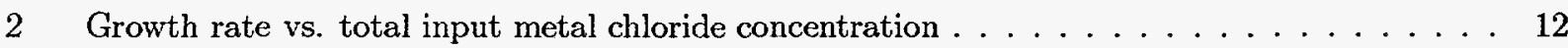

3 Growth rate vs. Input $\mathrm{Al} / \mathrm{Si}$ ratio with the input metal chloride concentration held at 0.40 torr. 13

4 Growth rate vs. Input metal chloride concentration with the input $\mathrm{Al} / \mathrm{Si}$ ratio held at $3 . \ldots 14$

$5 \quad$ Growth rate vs. $\mathrm{PAlCl} 3$ at a constant $\mathrm{PSiCl} 4$ of 0.13 torr $\ldots \ldots \ldots \ldots$

$6 \quad$ Growth rate vs. $\mathrm{PSiCl} 4$ at a constant $\mathrm{PAlCl} 3$ of 0.13 torr $\ldots \ldots \ldots$

7 a) Surface structure of the standard mullite coating on $\mathrm{SiC}$ at the top and bottom of the sample; b) Surface structure of a mullite coating on $\mathrm{SiC}$ with a 1.3 torr addition of $\mathrm{HCl} \ldots 18$

8 Growth rate vs. Input gas velocity $\ldots \ldots \ldots \ldots \ldots \ldots \ldots$

9 A typical TEM morphology of the CVD mullite coating on $\mathrm{SiC} \ldots \ldots \ldots \ldots$

10 HREM image of the interface between the nanocrystalline and mullite regions . . . . . . 24

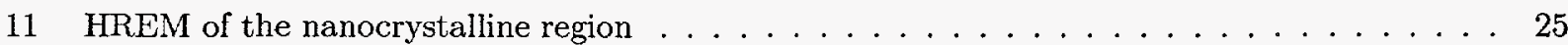

12 Thickness dependence of the nanocrystalline layer on the input $\mathrm{AlCl}_{3} / \mathrm{SiCl}_{4}$ ratio $\ldots \ldots 26$

13 Electron diffraction pattern of crystalline mullite along main zone axes $\ldots \ldots \ldots$

14 Phase transformation of the nanocrystalline layer after annealing at $1200{ }^{\circ} \mathrm{C}$ for 100 hours . . 28

15 Phase transformation of the nanocrystalline layer with extra $\mathrm{Al}$ available (a) a $\mathrm{Al}$ rich layer on top of the nanocrystalline layer, (b) a $\mathrm{Al}$ rich layer between the substrate and the nanocrys-

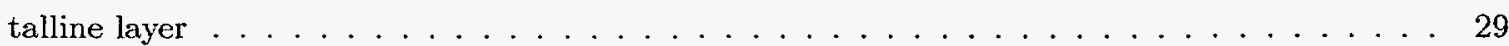

16 Cross-section of mullite coatings grown on a) SiC, b)Alumina, c)mullite $\ldots \ldots \ldots$

17 Microprobe micrograph of Illinois No.6 coal slag from Test 1. Crystallites are anorthite. . . . 36

18 Scanning electron micrograph of (a) alumina/slag interface from Test 1, 1000x, (b) Fe dot map highlighting corrosion product at interface $\ldots \ldots \ldots \ldots \ldots \ldots \ldots$

19 Scanning electron micrograph of (a) bulk mullite/slag interface from Test 1, 500x, (b) Fe dot

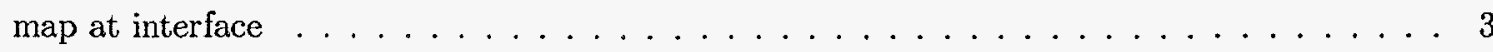

20 Optical micrographs of from Test 1: (a) Uncoated SiC corrosion interface, 100x, (b) CVD mullite coated $\mathrm{SiC}$ corrosion interface $100 \mathrm{x} . \ldots \ldots \ldots \ldots \ldots \ldots$ 
21 Uncoated SiC corrosion pit from Test1: (a) SEM micrograph, 200x , (b) Fe dot map dot $\operatorname{map}(\mathrm{c}) \operatorname{si} \operatorname{dot} \operatorname{map} \ldots \ldots \ldots \ldots \ldots \ldots \ldots \ldots \ldots \ldots \ldots$

22 Optical micrograph of 2 -phase iron silicide corrosion region from Test1. . . . . . . . . 41

23 CVD mullite coating region from Test1: (a)SEM of slag/mullite/coating interfaces, 2500X (b)

Al dot map, (c) Fe dot map, (d) Si dot map. . . . . . . . . . . . . . 42

24 Comparison of corrosion rates of Coated and Uncoated $\mathrm{SiC} \ldots \ldots \ldots \ldots$

\section{List of Tables}

1 Composition of mullite substrate (Coors Ceramic Co.) as determined by microprobe analysis 6

2 Composition and Base/Acid ratio of Illinois No.6 coal slag as determined by microprobe analysis 7

3 Coal slag corrosion test conditions $\ldots \ldots \ldots \ldots \ldots \ldots$

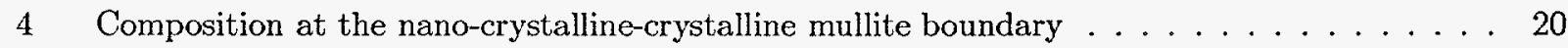

5 Diffraction Pattern of the Nano-Crystalline Region . . . . . . . . . . . . . 21

6 Microprobe analysis of the 2-phase iron silicide corrosion product at the SiC-slag interface . . 32

7 Average slag pitting depth and parabolic corrosion rate constant $\ldots \ldots \ldots \ldots$

8 Stress in selected materials caused by thermal expansion mismatch with the coal slag. . . . . 35 


\section{Introduction}

The continued interest in improving energy efficiency has led to extensive research related to improved fuel efficiencies in fossil fuel powered combustion processes. To raise the energy efficiency and reduce emissions of coal fired power systems, higher working fluid temperatures are required. Therefore, the traditional metal based heat exchangers which are limited to temperatures of $800^{\circ} \mathrm{C}$ to $900^{\circ} \mathrm{C}$, must be replaced by ceramic heat exchangers that can withstand working temperatures of up to $1400^{\circ} \mathrm{C}[1,2,3,4,5]$.

Silicon carbide-based materials such as sintered $\mathrm{SiC}$, siliconized $\mathrm{SiC}$, or a composite containing $\mathrm{SiC}$ are promising candidate materials for high temperature applications such as heat exchangers, gas turbines, and internal combustion engines. These materials possess a good combination of physical and mechanical properties such as high strength and thermal conductivity, low thermal expansion coefficients, as well as thermal shock and oxidation resistance at temperatures above $1000^{\circ} \mathrm{C}$. The oxidation resistance of these ceramics is due to the formation of a thin silica layer on the surface under oxidizing conditions. However, the usefulness of these materials is limited in the presence of molten salts. In the presence of these melts, the protective silica layer forms liquid silicates at temperatures as low as $800^{\circ} \mathrm{C}$ leading to rapid degradation of the ceramic by hot corrosion [6]. The coal gasification reaction produces an extremely corrosive wood ash deposit called coal slag. At high gasification operating temperatures $\left(\mathrm{T}>1100^{\circ} \mathrm{C}\right)$ the slag is liquidous and contains numerous oxides that react with the unprotected refractory lining of the process vessels. The reaction between liquid slag and silicon carbide-based ceramics results in severe pit formation, material loss, and increased porosity. Coal slag attack of $\mathrm{SiC}$ is well documented and has been shown to reduce the room temperature strength and fracture properties of the SiC-based ceramics [7].

The need to reduce and/or prevent coal slag corrosion, has led to the development of protective coatings that will enhance corrosion resistance in high temperature slag environments. The application of a thin refractory oxide coating to silicon carbide based materials has been studied as a possible method to improve coal slag corrosion resistance. Alumina $\left(\mathrm{Al}_{2} \mathrm{O}_{3}\right)$ based coatings have been studied by several researchers due to their superior corrosion resistance, but failed due to thermal expansion stresses between alumina and $\mathrm{SiC}[8]$. Further investigations have shown that alumina is unsuitable in the coal slag combustion environment 
due to cracking most likely caused by thermal expansion coefficient mismatch between the coal slag and alumina [4].

Mullite $\left(3 \mathrm{Al}_{2} \mathrm{O}_{3} \cdot 2 \mathrm{SiO}_{2}\right)$ has been targeted as a potential coating material for silicon carbide-based ceramics due to the close coefficient of thermal expansion match between the two materials and the reported superior corrosion resistance of mullite. Mullite has received considerable attention as a high temperature material because of its unique ability to retain its strength, resist creep, and avoid thermal shock failure at elevated temperatures $[9,10,11,12]$. Theoretically dense and homogenous bulk mullite ceramics are difficult to produce using traditional powder processing techniques. Previous attempts to grow mullite coatings by various processing methods have met with limited success[13]. Most commonly reported techniques require a post deposition heat treatment to convert the amorphous alumina-silicate into crystalline mullite [14, 15]. To overcome these deficiencies, the direct formation of chemically vapor deposited (CVD) mullite coatings has been investigated. The CVD process results in dense adherent coatings with the ability to control microstructural and morphological properties.

A systematic analysis of the thermodynamics and kinetics of the process is necessary in order to control the microstructure and morphology of the resultant coating. This information becomes increasingly important when depositing a multi-component system such as mullite [16]. Equilibrium thermodynamic analysis was performed on the CVD mullite system in order to establish equilibrium reaction products at various operating conditions and has been detailed in previous publications $[17,18]$. Kinetic data for deposition environments is sparse and usually limited to simple systems [19]. Initial kinetic evaluations on the CVD mullite system have been performed and continue in the present work [20]. Current research has focused upon the kinetics of mullite deposition, nucleation and growth evolution, as well as the thermal stability and protective properties of mullite coatings.

\section{Experimental Procedure}

A CVD reactor consisting of a vertical hot-walled reactor with a resistively heated three-zoned furnace was used for the deposition of CVD mullite coatings. The deposition techniques are detailed in previous literature [21]. The reactants used in the formation of mullite are $\mathrm{AlCl}_{3}, \mathrm{SiCl}_{4}, \mathrm{CO}_{2}, \mathrm{H}_{2}$, and $\mathrm{Ar}$ as a dilutant. $\mathrm{AlCl}_{3}$ is 


\begin{tabular}{|l|l|l|l|l|l|l|}
\hline Oxide Wt \% & $\mathrm{SiO}_{2}$ & $\mathrm{TiO}_{2}$ & $\mathrm{Al}_{2} \mathrm{O}_{3}$ & $\mathrm{FeO}$ & $\mathrm{MgO}$ & $\mathrm{CaO}$ \\
\hline \hline Mullite Grain & 25.45 & 0.61 & 69.82 & 0.33 & 0.08 & 0.0 \\
\hline Silicate Matrix & 71.89 & 2.517 & 13.43 & 1.8064 & 0.8278 & 0.6075 \\
\hline
\end{tabular}

Table 1: Composition of mullite substrate (Coors Ceramic Co.) as determined by microprobe analysis

formed by chlorinating heated $\mathrm{Al}$ chips; $\mathrm{SiCl}_{4}$ was introduced by evaporating the liquid at room temperature. Excess $\mathrm{H}_{2}$ was present to ensure complete reduction of the metal chlorides to form $\mathrm{HCl}$ before exiting the chamber. All CVD mullite coatings reported in this study were deposited at 75 torr and $950^{\circ} \mathrm{C}$. All coatings were characterized through X-ray diffraction (XRD) and scanning electron microscopy (SEM). Selected coatings were characterized with energy dispersive spectroscopy (EDS), transmission electron microscopy (TEM), and scanning transmission electron microscopy (STEM). Electron probe microanalysis (EPMA) of corrosion products and substrate composition was performed using a JEOL JXA-733 superprobe.

In order to investigate possible the phase transformations within the nanocrystalline layer, three types of coatings were deposited on $\mathrm{SiC}$ substrates: 1) Only a nanocrystalline layer; 2) An $\mathrm{Al}$ rich layer between the substrate and the nanocrystalline layer; 3). A nanocrystalline layer and an Al rich layer on the top. A thin $\mathrm{Al}$ rich layer was achieved on the bottom and the top of the coating by simply switching off the $\mathrm{SiCl}_{4}$ flow at the first and last 30 minutes of the experiment. These samples were annealed at $1200^{\circ} \mathrm{C}$ for up to 100 hours.

Four different materials were tested in the coal slag corrosion environment: $\alpha-\mathrm{Al}_{2} \mathrm{O}_{3}$, mullite, $\mathrm{SiC}$, and CVD mullite coated SiC. Polished bars of $3 \times 4 \times 20 \mathrm{~mm}$ Hexaloy SiC (Carborundum Co., Niagara Falls, N.Y.), $\alpha-\mathrm{Al}_{2} \mathrm{O}_{3}$, and mullite (Coors Ceramic Co., Golden, $\mathrm{CO}$ ) were prepared to a 600 grit finish. X-ray diffraction of the $\mathrm{Al}_{2} \mathrm{O}_{3}$ revealed corundum $(\alpha)$ to be the only crystalline phase. X-ray diffraction of the $\mathrm{SiC}$ revealed a mixture of hexagonal and cubic phases $(6 \mathrm{H}, 4 \mathrm{H}, 2 \mathrm{H}, 4 \mathrm{C})$. Orthorhombic mullite was the only crystalline phase detected in the as received mullite substrates, although microprobe analysis indicated that the material was a porous heterogeneous mixture of mullite grains containing trace amounts of $\mathrm{FeO}, \mathrm{TiO}_{2}$, and $\mathrm{MgO}$ in an $\mathrm{SiO}_{2}$-rich matrix containing significant amounts of $\mathrm{Al}_{2} \mathrm{O}_{3}$ with trace amounts of $\mathrm{FeO}, \mathrm{TiO}_{2}$, and $\mathrm{MgO}$ (see Table 1).

The coal slag utilized was formed from Illinois No. 6 wood ash. Illinois No. 6 is an iron rich acidic wood ash deposit found in Eastern US Coal Power Plants (Table 2). It was collected at the Illinois Power Company's 


\begin{tabular}{|l|l|l|l|}
\hline Oxide & Wood Ash & Cryst. Slag & Uncryst. Slag \\
\hline \hline & Wt \% & Wt \% & Wt \% \\
\hline $\mathrm{SiO}_{2}$ & 53.4 & 57.38 & 57.56 \\
\hline $\mathrm{Al}_{2} \mathrm{O}_{3}$ & 18.6 & 18.71 & 17.32 \\
\hline $\mathrm{Fe}_{2} \mathrm{O}_{3}$ & 17.6 & 13.54 & 12.87 \\
\hline $\mathrm{TiO}_{2}$ & 0.7 & 0.902 & 0.9955 \\
\hline $\mathrm{P}_{2} \mathrm{O}_{5}$ & 0.0 & 0.0416 & 0.0016 \\
\hline $\mathrm{CaO}$ & 7.1 & 3.44 & 3.56 \\
\hline $\mathrm{MgO}$ & 0.9 & 1.6843 & 1.6494 \\
\hline $\mathrm{Na}_{2} \mathrm{O}$ & 0.0 & 0.1601 & 0.1657 \\
\hline $\mathrm{K}_{2} \mathrm{O}$ & 1.7 & 1.7911 & 1.9217 \\
\hline $\mathrm{SO}_{3}$ & 0.1 & 0.0 & 0.0 \\
\hline $\mathrm{Base}$ Acid & 0.376 & 0.268 & 0.266 \\
\hline
\end{tabular}

Table 2: Composition and Base/Acid ratio of Illinois No.6 coal slag as determined by microprobe analysis

Baldwin Plant and supplied by the Energy and Environmental Research Center at the University of North Dakota. Initially, the coal slag used to perform these corrosion studies was in the form of an amorphous grey colored wood ash. In order to remove excess carbon from the wood ash, it was preheated in an alumina crucible at $900^{\circ} \mathrm{C}$ for four hours under a simulated gasification atmosphere[22].

A coal slag corrosion unit was built at the Boston University Surface Modification Laboratory for the slag corrosion studies. The unit has a controllable atmosphere with a high temperature reaction chamber. The atmosphere of the gasifier was simulated by $30 \% \mathrm{H}_{2}, 45 \% \mathrm{CO}$, and $25 \% \mathrm{CO}_{2}$ [22]. The trays were placed inside of the furnace reaction chamber and ramped up to the test temperature of $1260^{\circ} \mathrm{C}$. Assuming that the input gasses react to thermodynamic equilibrium at $1260^{\circ} \mathrm{C}$ a reducing environment is present with $\frac{\mathrm{H}_{2}}{\mathrm{H}_{2} \mathrm{O}}=1.61$ and $\frac{\mathrm{CO}}{\mathrm{CO}_{2}}=4.19$. A test temperature of $1260^{\circ} \mathrm{C}$ was chosen to simulate the actual operating temperature inside a typical coal gasifier[23].

Four different types of coal slag corrosion tests were performed. Test 1 was a continuous 300 hour exposure at the test temperature $1260^{\circ} \mathrm{C}$, the atmosphere simulated gasification conditions at a pressure of 40 torr. Test 1 was performed to determine the long term corrosion resistance of the samples. Tests 2,3 , and 4 were a short duration time study to determine the corrosion mechanisms and rates governing the diffusion and corrosive reactions between the slag and test samples. The time study was performed at $1260^{\circ} \mathrm{C}$, atmospheric pressure (760 torr), with an air atmosphere (Table 3).

Thermodynamic analysis of possible coal slag corrosion reactions with CVD mullite coatings, $\mathrm{SiC}, \alpha-$ $\mathrm{Al}_{2} \mathrm{O}_{3}$, and mullite were performed using SOLGAS MIX PV, free energy calculations were obtained with 


\begin{tabular}{|l|l|l|l|}
\hline Test & Duration & Temp & Atmosphere \\
\hline \hline 1 & $300 \mathrm{hrs}$ & $1260^{\circ} \mathrm{C}$ & $30 \% \mathrm{H}_{2}, 45 \% \mathrm{CO}, 25 \% \mathrm{CO}_{2}$ \\
\hline 2 & $10 \mathrm{hrs}$ & $1260^{\circ} \mathrm{C}$ & Air \\
\hline 3 & $20 \mathrm{hrs}$ & $1260^{\circ} \mathrm{C}$ & Air \\
\hline 4 & $40 \mathrm{hrs}$ & $1260^{\circ} \mathrm{C}$ & Air \\
\hline
\end{tabular}

Table 3: Coal slag corrosion test conditions

$\mathrm{F}^{*} \mathrm{~A}^{*} \mathrm{C}^{*} \mathrm{~T}[28,29]$. These software systems are based upon a minimization of Gibb's free energy of all possible reactant species. Hardness values were collected using a Knoop microindentor at a $25 \mathrm{~g}$ load with a Wilson Tukon ${ }^{\circledR}$ Series 200 hardness tester.

\section{Results and Discussion}

Current efforts on the CVD mullite system have been divided into three separate areas: 1) Deposition process conditions, and the effects on the resultant coating, 2) The thermal stability and structure of the coating substrate system, 3) The properties of CVD mullite coatings in a coal gasification environment.

\subsection{Processing Conditions}

CVD mullite coatings exhibit an unusual coating evolution on Si-based substrates $[17,30]$. The coating initiates as a nano-sized mixture of $\gamma-\mathrm{Al}_{2} \mathrm{O}_{3}$ in an amorphous $\mathrm{SiO}_{2}$ matrix. As the coating grows away from the substrate the $\mathrm{Al} / \mathrm{Si}$ ratio steadily increases. When the ratio reaches a critical ratio of $\sim 3 / 1$ the columnar mullite grains begin growing with a steadily increasing $\mathrm{Al} / \mathrm{Si}$ ratio. The causes of this evolution are poorly understood, and will be further discussed in Sec. 3.2. The influences of process variables such as metal chloride concentrations and input $\mathrm{Al} / \mathrm{Si}$ upon the coating growth rate and morphology are discussed in the present section.

Achieving a given input $\mathrm{Al} / \mathrm{Si}$ ratio is achieved by proportionally varying the flow rates of $\mathrm{AlCl}_{3}$ and $\mathrm{SiCl}_{4}$ into the deposition reactor. There are several methods to achieve the desired ratio including: 1) varying the $\mathrm{SiCl}_{4}$ flow rate and holding $\mathrm{AlCl}_{3}$ constant, 2) varying the $\mathrm{AlCl}_{3}$ flow rate and holding $\mathrm{SiCl}_{4}$ constant, and 3) varying both $\mathrm{AlCl}_{3}$ and $\mathrm{SiCl}_{4}$ and holding the total metal chloride concentration constant. Each of these methods has been investigated and is discussed. The total metal chloride concentration is referred to 
as $P_{M C l x}$, which is the partial pressure sum of $\mathrm{AlCl}_{3}$ and $\mathrm{SiCl}_{4}$, or $P_{A l C l 3}$ and $P_{S i C l 4}$.

Figure 1 is a plot of growth rate vs. input $\mathrm{Al} / \mathrm{Si}$ ratio without regard to the partial pressures of the reactant chlorides. The plot reveals no obvious correlation between growth rate and input $\mathrm{Al} / \mathrm{Si}$ ratio. Characterization of the coatings using $\mathrm{X}$-ray diffraction reveals that coatings grown with a growth rate greater than $15 \mu \mathrm{m} / \mathrm{hr}$ are generally amorphous. Coatings grown with a slower growth rate are crystalline mullite. Simply controlling the input $\mathrm{Al} / \mathrm{Si}$ ratio without regard for the input metal chloride concentration does not allow for control over the coating's growth rate or microstructure.

As mentioned previously, the input ratio may be achieved through several different variations in metal chloride concentrations. The data in Figure 1 has been replotted in Figure 2 according to the total input metal chloride concentration $P_{M C l x}$. The growth rate decreases with increasing total metal chloride concentration. This trend is quite surprising as one would expect that as the total concentration of reactants increases the amount of product should also increase. One explanation for the reversal of the expected growth trend and structure is the formation of homogenous nuclei, or powder formation. Simple homogenous nucleation theory (Eqn. 1, [31])

$$
J_{n}=n_{s} \exp \left[\frac{-\Delta G}{k T}\right] 4 \pi r^{2} \frac{\alpha\left(P_{v}-P_{s}\right) N a}{\sqrt{2 \pi M R T}}
$$

indicates that small changes in temperature and supersaturation create extreme differences in the homogenous nucleation rate. These extreme fluctuations in nucleation rate may create extreme changes in the film deposition rate through depletion. Impurities in the gas phase also have the potential of acting as nucleation sites, thus drastically altering the resultant deposition rate. The lower reactant concentrations result in less homogenous nucleation. As a result there is a relatively large amount of reactant available for coating formation, or a high supersaturation of reactants at the growth surface.

With this information, the growth rate dependence upon the $\mathrm{Al} / \mathrm{Si}$ ratio shall be replotted yet with a constant $P_{M C l x}$ as shown in Figure 3. The growth rate is relatively constant across all $\mathrm{Al} / \mathrm{Si}$ ratios except for a slight increase in the growth rate at the stoichiometric ratio of 3 . Stoichiometric mullite $\left(3 \mathrm{Al}_{2} \mathrm{O}_{3} \cdot 2 \mathrm{SiO}_{2}\right)$ has an $\mathrm{Al} / \mathrm{Si}$ ratio of 3 . The slight increase in the growth rate at the stoichiometric ratio may be explained through the observation of mullite coating evolution. It has been observed that the growth rate of the columnar mullite structure is more rapid than the initial nanocrystalline layer [17]. X-ray diffraction analysis 
of the coatings grown with an input ratio of $3 / 1$ reveal a highly textured coating in the (001) direction, as will be discussed further in Sec. 3.2. This growth direction corresponds to the lowest energy growth direction when mullite is prepared using numerous traditional and non-traditional means [32].

Stoichiometric mullite $\left(3 \mathrm{Al}_{2} \mathrm{O}_{3} \cdot 2 \mathrm{SiO}_{2}\right)$ has an $\mathrm{Al} / \mathrm{Si}$ ratio of 3 so careful attention has been paid to coatings grown within this ratio. As can be seen in Figure 1 a large variation in growth rate has been achieved at this input ratio. Figure 4 further constrains the reactant metal chloride to the stoichiometric ratio of $3 / 1$.

The final two methods of altering $P_{M C l x}$ investigated are altering either $P_{\mathrm{Si} C l 4}$ or $P_{A l C l 3}$ and holding the other constant. The growth rate decreases with increasing individual metal chloride concentration. These trends are shown in Figures 5, $6 \mathrm{~A}$ critical value of $P_{A l C l 3}$ seems to exist between 0.13 and 0.27 torr where a dramatic decrease in growth rate takes place. Homogenous nucleation theory (Eqn. 1) exhibits a critical supersaturation where a dramatic increase in homogenous nucleation occurs.

Input gas stoichiometry and reactant concentration have a tremendous effect upon the microstructure, morphology, and growth rate of the resultant coating. Studies in this area are a continuation of previous investigations [16]. These results have shown that the resultant coating is dependent upon both the input $\mathrm{Al} / \mathrm{Si}$ ratio and the concentrations of $\mathrm{AlCl}_{3}$ and $\mathrm{SiCl}_{4}$. The deposition system is not mass transport limited with regard to the metallic elements. A similar growth trend has been reported in the $\mathrm{CVD} \mathrm{Al}_{2} \mathrm{O}_{3}$ system deposited from $\mathrm{AlCl}_{3}, \mathrm{H}_{2}, \mathrm{CO}_{2}[33]$.

\subsubsection{Gas Velocity and Uniformity}

The uniformity of the deposited coating is an important issue, and one that is particularly sensitive in CVD oxide coatings. Previous results have revealed that CVD mullite is susceptible to non-uniformity due to either gas-phase depletion or temperature differences on the deposition surface [34]. The dependence between growth rate and the partial pressure of reactants reveals that powder formation is a significant issue for the mullite system within the deposition environment. The kinetics of gas phase and surface reactants are dominating the properties of the resultant coating. Reducing powder formation may be achieved through Le'Chatelier's Principle where small additions of products gases to the reactant mixture will decrease product 


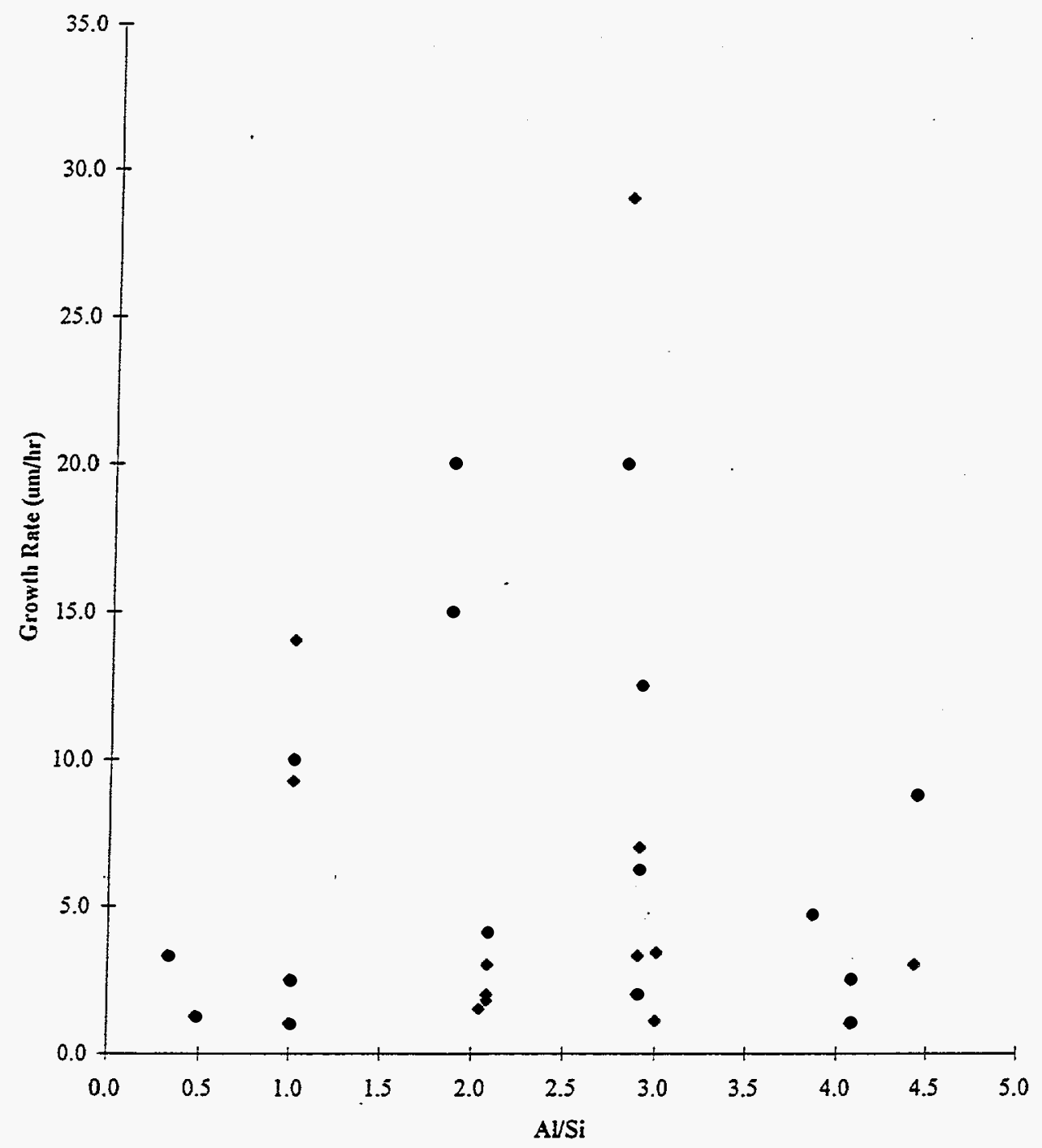

Figure 1: Growth Rate vs. Input $\mathrm{Al} / \mathrm{Si}$ without regard for metal chloride concentration 


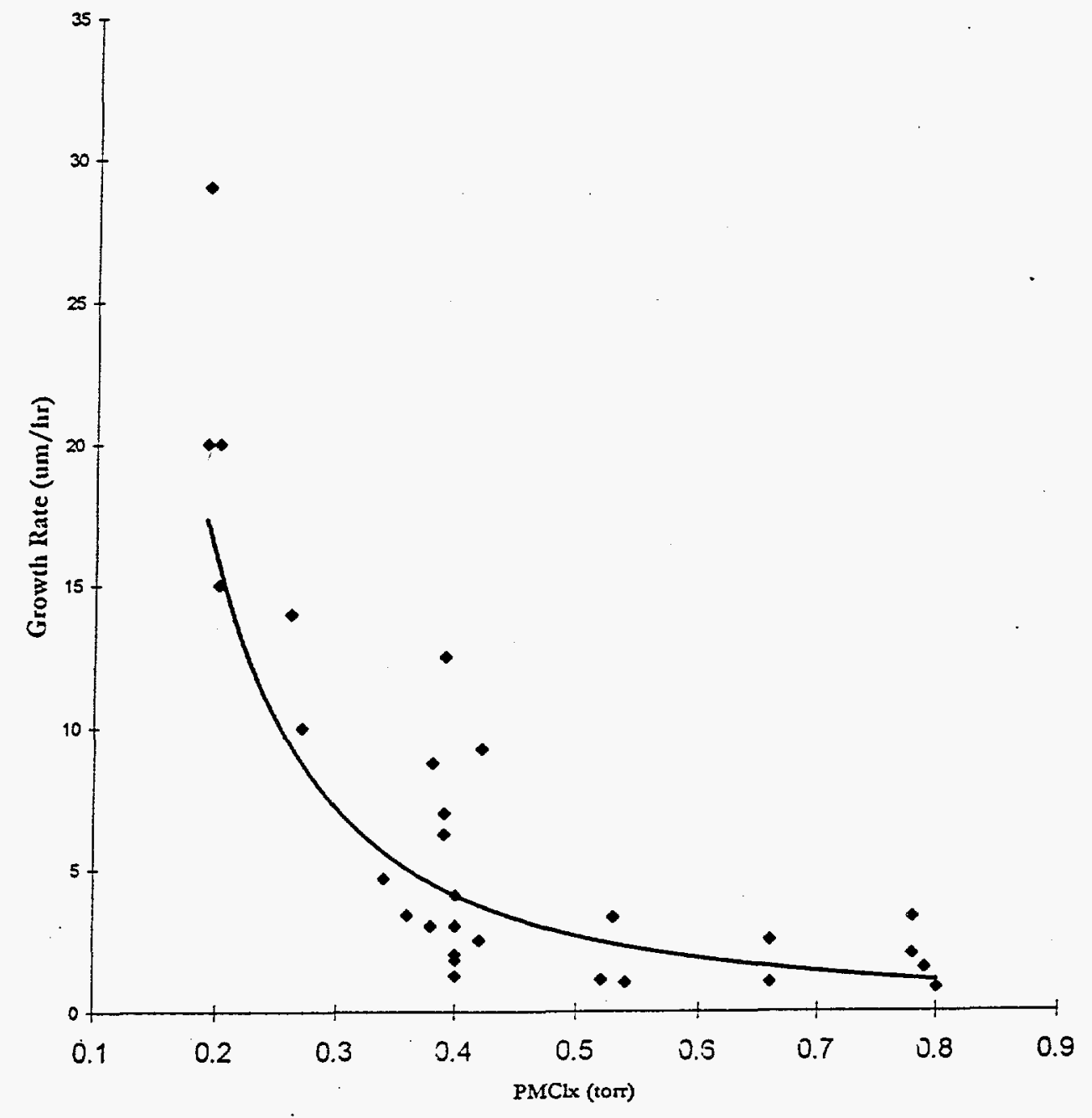

Figure 2: Growth rate vs. total input metal chloride concentration 


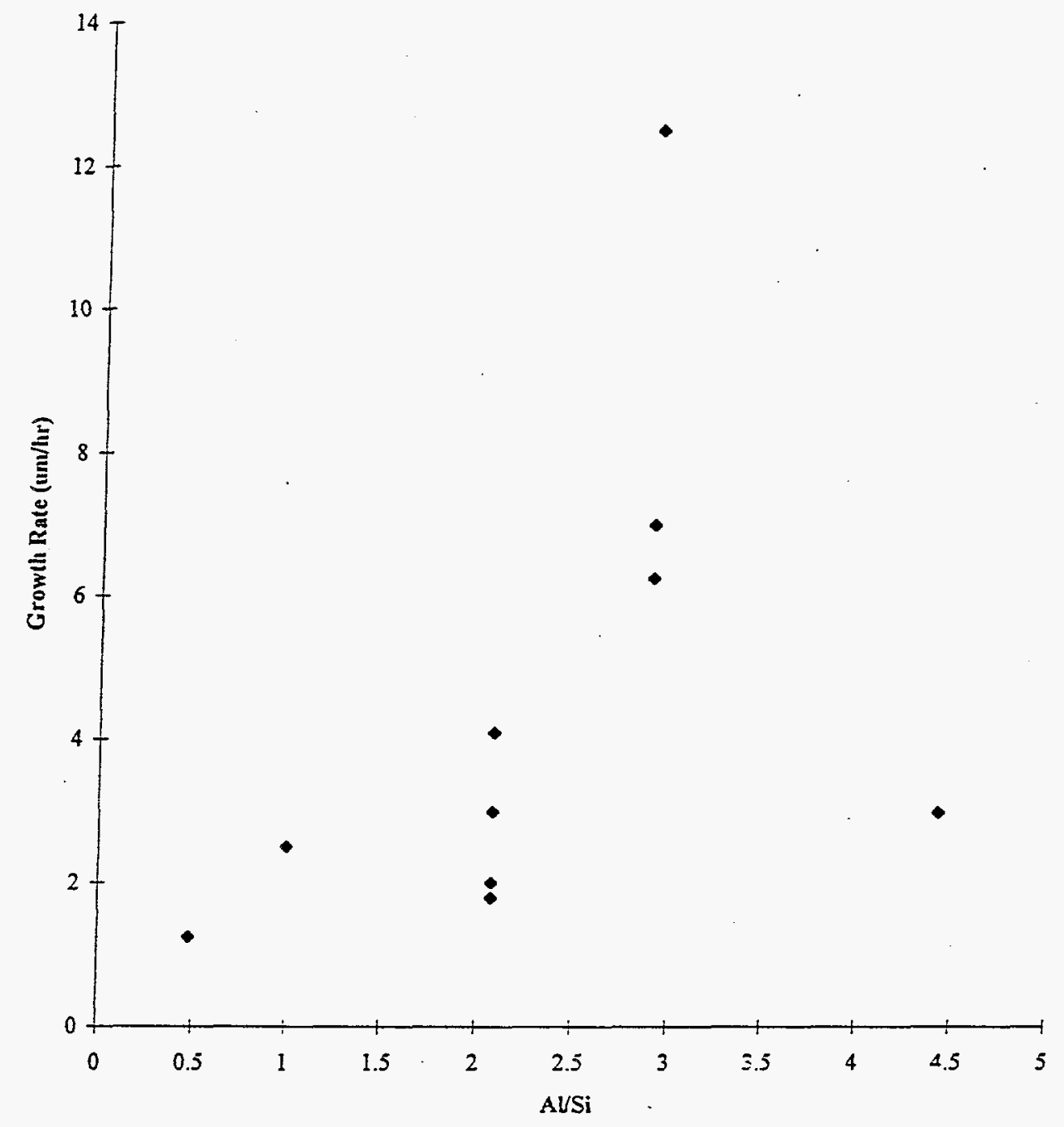

Figure 3: Growth rate vs. Input $\mathrm{Al} / \mathrm{Si}$ ratio with the input metal chloride concentration held at 0.40 torr. 


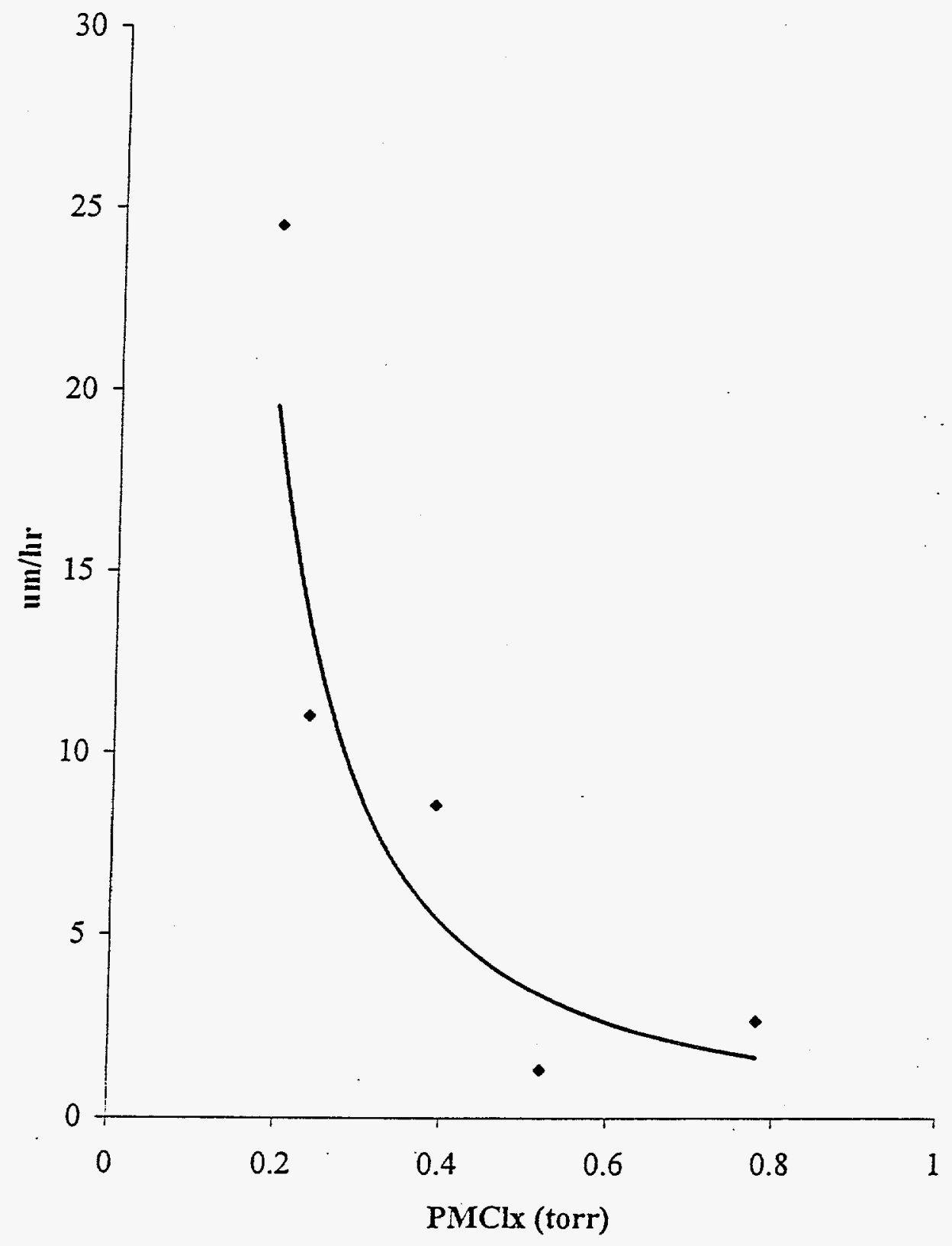

Figure 4: Growth rate vs. Input metal chloride concentration with the input $\mathrm{Al} / \mathrm{Si}$ ratio held at 3. 


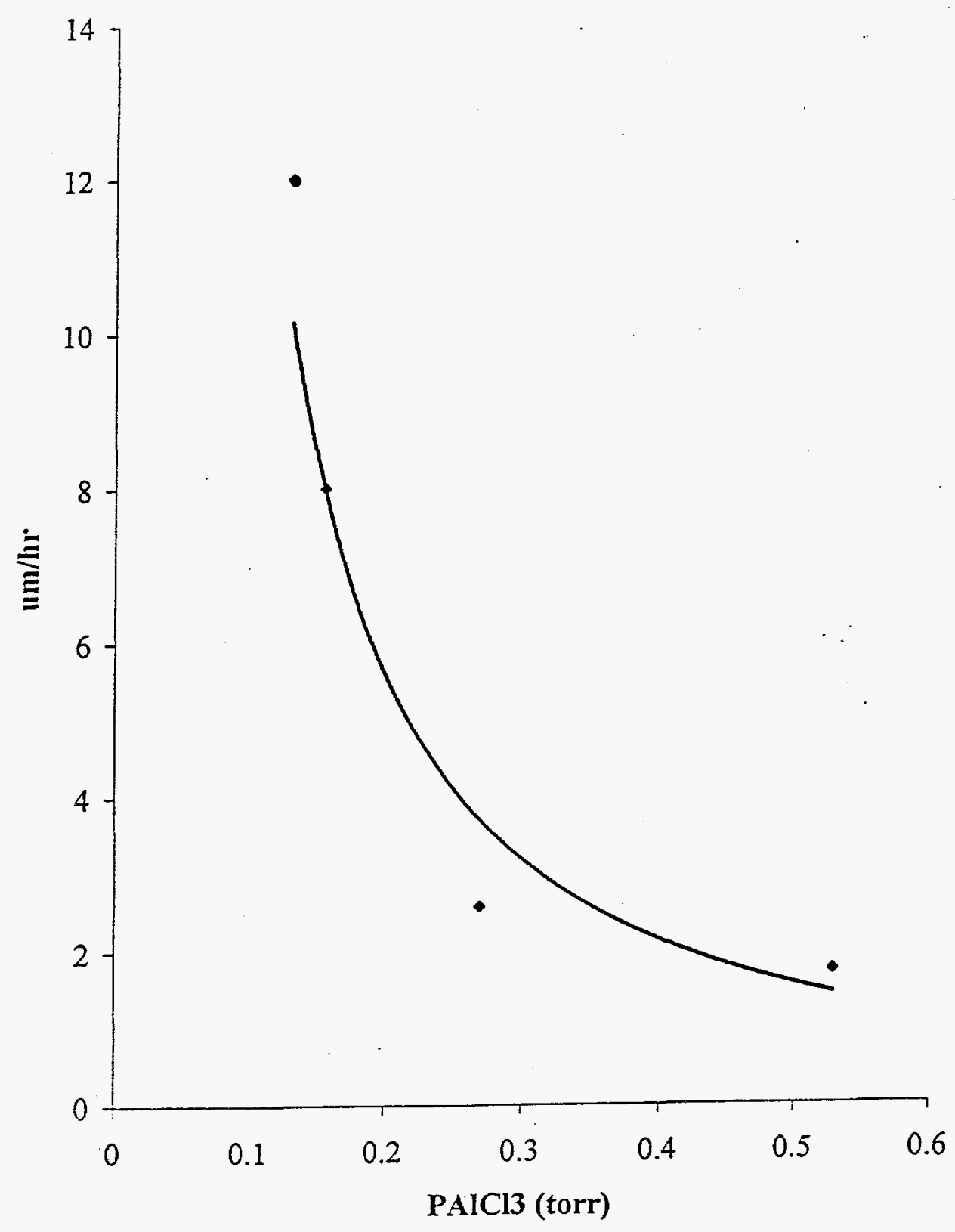

Figure 5: Growth rate vs. $\mathrm{PAlCl} 3$ at a constant PSiCl4 of 0.13 torr 


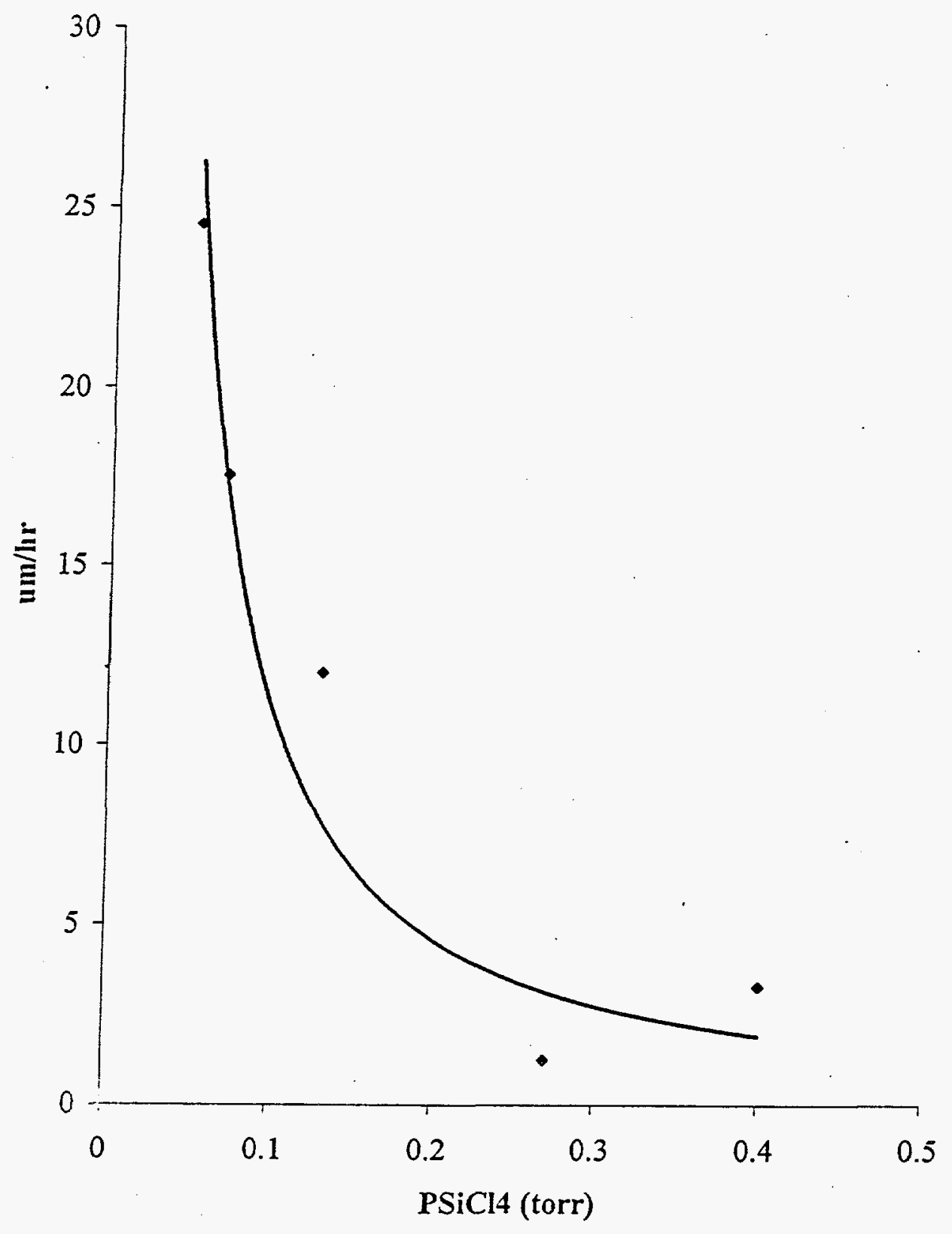

Figure 6: Growth rate vs. PSiCl4 at a constant $\mathrm{PAlCl} 3$ of 0.13 torr 
formation.

It is speculated that powder formation in this system is related to the reduction of the metal chlorides with $\mathrm{H}_{2}$, forming $\mathrm{HCl}$ and subsequent metal combination with $\mathrm{H}_{2} \mathrm{O}$ to form a metal oxide species. The addition of $\mathrm{HCl}$ to the reactant gases may slow this gas phase formation reducing the thermodynamic driving force for product formation. The overall reaction is given below in Eqn. 2 where the forward reaction constant $\mathrm{K}_{p}$ is determined by $\Delta \mathrm{G}=-\mathrm{RT} \ln \mathrm{K}_{p}$.

$$
6 \mathrm{AlCl}_{3}+2 \mathrm{SiCl}_{4}+13 \mathrm{H}_{2}+13 \mathrm{CO}_{2} \rightarrow 3 \mathrm{Al}_{2} \mathrm{O}_{3} \cdot 2 \mathrm{SiO}_{2}+13 \mathrm{CO}+26 \mathrm{HCl}
$$

Experimental results reveal that slight additions of $\mathrm{HCl}$ have drastically reduced the amount of gas phase depletion and increased the uniformity of the coating. Figure 7 illustrates the effect of a 1.3 torr addition of $\mathrm{HCl}$. The samples were placed vertically within the reactor with the gas stream entering at the bottom of the sample and exiting at the top. The sample with the $\mathrm{HCl}$ added to the reactant mixture is uniform in structure, morphology, and growth rate; whereas the sample without $\mathrm{HCl}$ added is non-uniform. From these results it can be concluded that a majority of the non-uniformity previously exhibited in this system was due to gas phase depletion and not temperature disparities on the deposition surface.

The second method of reducing homogenous nucleation is to reduce residence time available for the formation of critical nuclei. The effect of gas velocity on growth rate is shown in Figure 8 . As the gas velocity increases the growth rate decreases. This is another strong indication that the coating is within the kinetically controlled regime as opposed to mass transport control. Similar results have been reported for both $\mathrm{SiO}_{2}$ and $\mathrm{Al}_{2} \mathrm{O}_{3}$ deposition using the same precursors [35, 36]. The coatings grown at the higher velocities are also more uniform with less gas phase nucleation occurring.

\subsection{Microstructures of the CVD Mullite Coating}

\subsubsection{Mullite Coating on SiC Substrate}

The kinetics of multi-component CVD coatings are complex. Critical kinetic reactions are occurring in the gas phase (homogeneously) and on the substrate surface (heterogeneously). On an Si-based material 


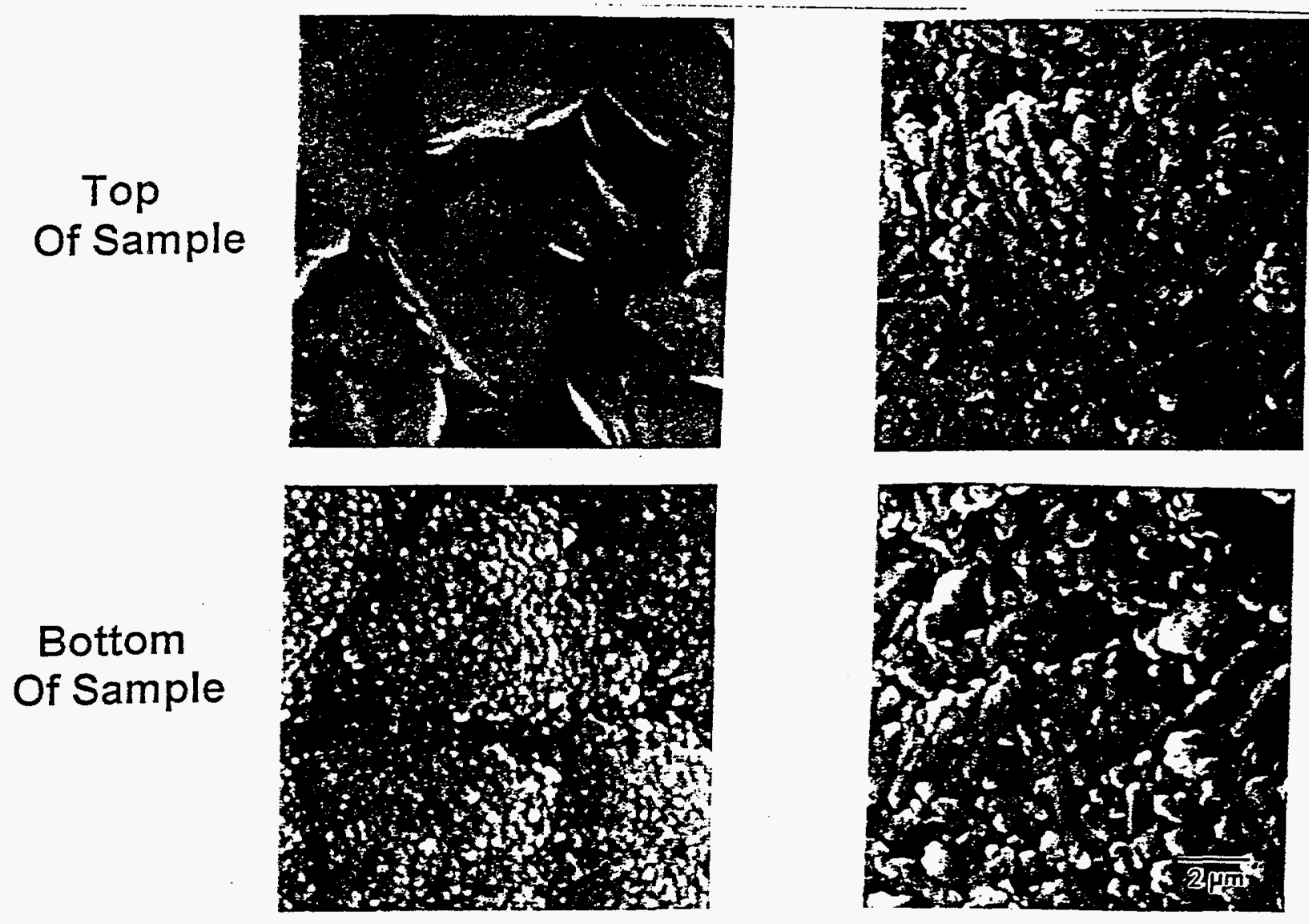

Figure 7: a) Surface structure of the standard mullite coating on $\mathrm{SiC}$ at the top and bottom of the sample;

b) Surface structure of a mullite coating on $\mathrm{SiC}$ with a 1.3 torr addition of $\mathrm{HCl}$ 


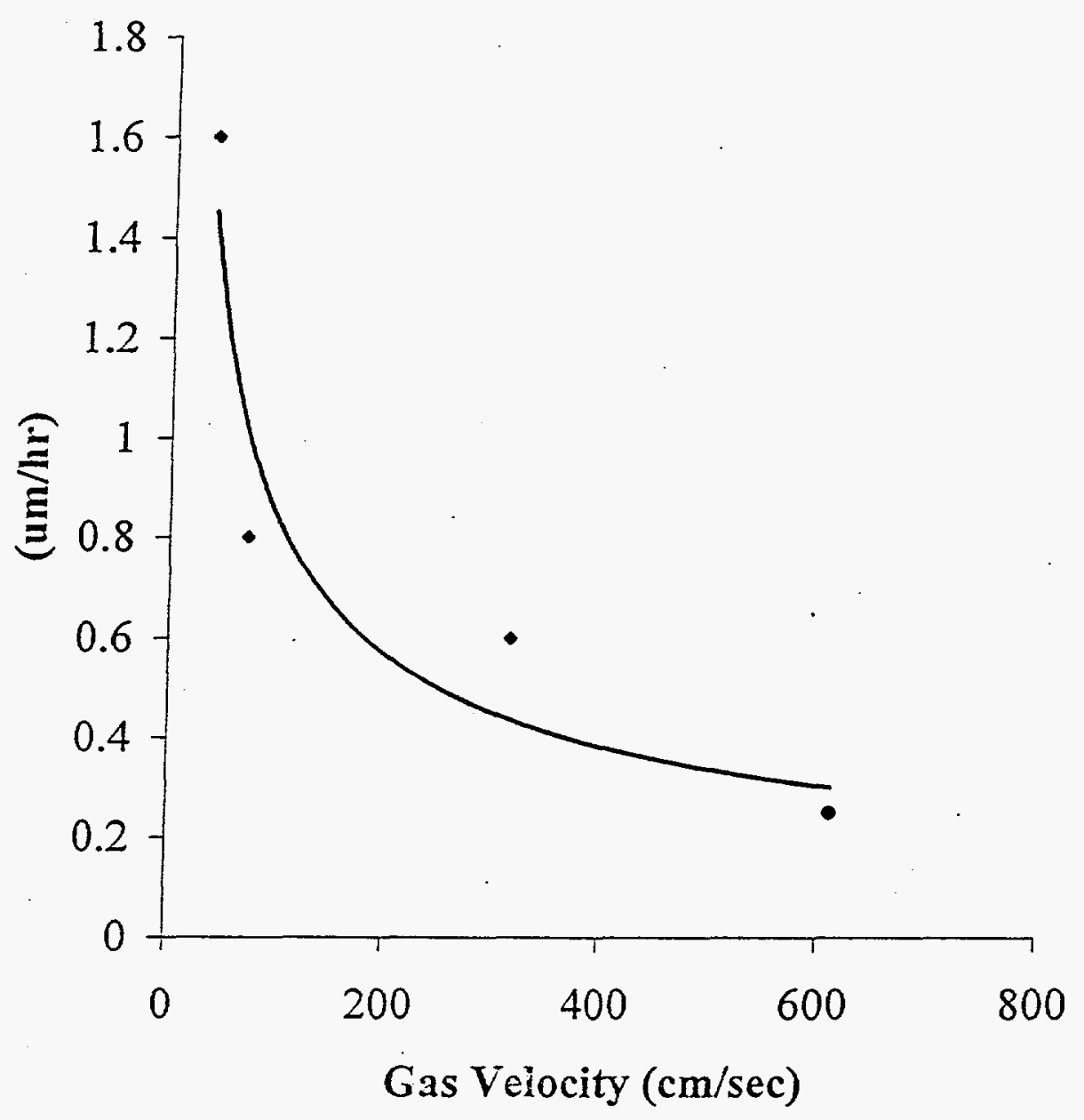

Figure 8: Growth rate vs. Input gas velocity 


\begin{tabular}{|l|l|l|}
\hline Input Al/Si & $\mathrm{Al} / \mathrm{Si}$ @ boundary & $\sigma_{x}$ \\
\hline \hline 2 & 3.13 & 0.25 \\
\hline 3 & 3.27 & 0.32 \\
\hline
\end{tabular}

Table 4: Composition at the nano-crystalline-crystalline mullite boundary

the coating initiates as a nano-sized mixture of $\gamma-\mathrm{Al}_{2} \mathrm{O}_{3}$ in an amorphous matrix. As the coating grows away from the substrate the $\mathrm{Al} / \mathrm{Si}$ ratio in the coating steadily increases. When the ratio reaches a critical ratio of $\sim 3 / 1$ columnar mullite grains nucleate. An input $\mathrm{Al} / \mathrm{Si}$ ratio of $<3$ results in a relatively thick nano-crystalline layer, whereas an $\mathrm{Al} / \mathrm{Si}$ ratio $>3$ results in a relatively thin nano-crystalline layer.

The unusual nucleation and growth evolution of CVD mullite on Si-based substrates has lead to an investigation of this phenomenon. The results indicate that there is a kinetic dependence within the gas phase and on the nucleating surface. These parallel kinetic dependencies has been observed for the deposition of $\mathrm{SiO}_{2}$ and $\mathrm{Al}_{2} \mathrm{O}_{3}$ using the same precursors $[35,36]$. These parallel dependencies have been described as the dependence on the water-gas shift reaction (Eqn. 3). It is believed that the reaction between the metal chlorides and $\mathrm{H}_{2} \mathrm{O}$ take place in the gas phase and on the deposition surface.

$$
\mathrm{CO}_{2}+\mathrm{H}_{2} \rightarrow \mathrm{H}_{2} \mathrm{O}+\mathrm{CO}
$$

The $\mathrm{Al} / \mathrm{Si}$ variance of coatings grown with an input ratio of 2 and 3 were analyzed by STEM and it was observed that the $\mathrm{Al} / \mathrm{Si}$ ratio of the coating increased as the coating grew way from the substrate. The composition at the nano-crystalline/crystalline boundary was evaluated and is summarized in Table 4.. The average $\mathrm{Al} / \mathrm{Si}$ ratio at the boundary of the two samples is very close, a single-factor variance analysis reveals that the average values are the same for the two samples. Essentially the transition from nano-crystalline $\gamma-\mathrm{Al}_{2} \mathrm{O}_{3}$ to columnar mullite has taken place at the same composition point in the coating. The thickness of the nano-crystalline layer changes with the input $\mathrm{Al} / \mathrm{Si}$ ratio, but the transition to columnar mullite is dependent upon the composition of the coating.

In general, composition, particle size, and degree of mixing of precursor materials are considered to be the most important factors for mullite formation. The formation of mullite depends on short distance diffusion or re-arrangement of precursor atoms for homogeneous mixing [24, 25]. In the CVD process, multi-components mix and react at the atomic or molecular level. 


\begin{tabular}{|c|c|c|c|c|}
\hline $\mathrm{d}_{h k l}^{*}(\AA)$ & $\mathrm{d}_{h k l}^{* *}(\AA)$ & $\mathrm{d}_{h k l}\left(\gamma-\mathrm{Al}_{2} \mathrm{O}_{3}\right)$ & $\mathrm{hkl}$ & $\mathrm{I} / \mathrm{I}_{0}$ \\
\hline 1.924 & 1.977 & 1.977 & 400 & 100 \\
\hline 1.347 & 1.384 & 1.395 & 440 & 100 \\
\hline 1.009 & 1.130 & 1.140 & 444 & 20 \\
\hline 0.955 & 0.981 & 0.989 & 800 & 10 \\
\hline 0.855 & 0.879 & 0.884 & 840 & 10 \\
\hline 0.781 & 0.802 & 0.806 & 844 & 20 \\
\hline
\end{tabular}

Table 5: Diffraction Pattern of the Nano-Crystalline Region

The typical profile morphology of the CVD mullite coating on Si-based substrate has two layers in sequence: nanocrystalline layer and columnar crystalline layer, Figure 9. There is no obvious transient region between the two layers (Figure 10). Since the electron diffraction pattern from the nanocrystalline layer is a series of concentric rings, this region must contain very fine polycrystalline particles. A high resolution micrograph of the nanocrystalline layer reveals the existence of equiaxed nano-crystals embedded in the amorphous structure (Figure 11).

The most interesting phenomenon related to coating deposition conditions is the decrease of the nanocrystalline layer thickness with the increased input $\mathrm{Al} / \mathrm{Si}$ ratio from 1:1 to 4:1 (Figure 12). It is speculated that the nanocrystalline layer thickness is related to the availability of $\mathrm{Al}$ atoms nucleating onto the coating surface. The faster the $\mathrm{Al}$ atoms deposit onto the surface the thinner the nano-crystal layer. Increasing the input partial pressure $\left(P_{A l C l 3}\right)$ will increase the flux of $\mathrm{AlCl}_{3}$ to the surface. The incubation time for mullite formation and thus the thickness of nanocrystalline layer can be reduced by increasing the input $\mathrm{Al} / \mathrm{Si}$ ratio.

The electron diffraction patterns from the nanocrystalline layer are confirmed to be the same for all samples under different CVD conditions. Calculated interplanar spacings from these diffraction rings are listed in Table 5. This diffraction pattern matches $\gamma-\mathrm{Al}_{2} \mathrm{O}_{3}$ with an average $0.59 \%$ error Electron diffraction patterns from the columnar crystal layer were obtained along main zone axis, like [001], [100], and [001] (Figure 13). All of these patterns match crystalline mullite. Based on the diffraction pattern obtained from [001] axis, it is shown that $\mathrm{a}=\mathrm{b}$ within the range of measurement error, which means that the as-deposited coating is tetragonal mullite.

A sample with only a nanocrystalline coating (no columnar mullite) was annealed @ $1200^{\circ} \mathrm{C}$ for up to 100 hours. There are no crystalline peaks for the as-deposited coating. Cristobalite $\left(\mathrm{SiO}_{2}\right)$ began to appear after annealing, and its intensity increased with annealing time (Figure 14). Compared with the standard 
spectrum of polycrystalline cristobalite powder, the average position of the peaks shifted to the left of the strongest (101) peak of cristobalite by $2 \theta=0.15^{\circ}$. It might be caused by two reasons: (1) lattice distortion of materials; (2) sample deviation from the center of the diffractometer. An experiment, in which the sample was deliberately loaded $0.2 \mathrm{~mm}$ lower and higher off the diffractometer center, was designed to examine the influence of the sample position. The result showed that the average shift of $2 \theta$ was about $0.10^{\circ}$ in our system. It was, however in practical operation, improbable to have such a large amount of deviation when loading samples. Thus the shift of the peak is caused by the distortion of the crystal lattice. Some $\mathrm{xSiO}_{2} \cdot(1-\mathrm{x}) \mathrm{Al}_{2} \mathrm{O}_{3}$ phases may form at elevated temperature, which caused a slight dilation of the $\mathrm{SiO}_{2}$ lattice. If a thin $\mathrm{Al}$-rich layer was deposited below or above the nanocrystalline layer, it will crystallize to mullite after annealing (Figure15). Extra $\mathrm{Al}$ must be available for the formation of crystalline mullite in the nanocrystalline layer.

\subsubsection{Mullite Coatings on Other Substrates}

The substrate dependence upon the growth evolution of the coating has been investigated by comparing coatings grown on $\mathrm{SiC}, \mathrm{Al}_{2} \mathrm{O}_{3}$, and mullite substrates. SEM micrographs of these coatings are given in Figure 16. Using STEM and EDS it was determined that the CVD mullite on SiC has evolved as expected beginning as a nano-crystalline layer of $\gamma-\mathrm{Al}_{2} \mathrm{O}_{3}$ and amorphous $\mathrm{SiO}_{2}$. The CVD mullite grown on a solid mullite substrate has grown as nanocrystalline mullite throughout the coating. The CVD mullite grown on $\mathrm{Al}_{2} \mathrm{O}_{3}$ has an initial nanocrystalline layer that is rich in $\mathrm{Al}$. The Si content steadily increases as the coating grows away from the $\mathrm{Al}_{2} \mathrm{O}_{3}$ substrate. Once the ratio reaches an $\mathrm{Al} / \mathrm{Si}$ ratio ${ }^{\sim} 3.1$ the coating converts to mullite with an increasing Al-content. The nucleation of the Si containing oxide is initially preferred on Sibased substrates. The nucleation of mullite on mullite is preferred, and the nucleation of the $\mathrm{Al}$ containing oxide is preferred on $\mathrm{Al}_{2} \mathrm{O}_{3}$.

\subsection{Post Exposure Coal Slag}

After 300 hours of exposure during Test 1 (Table 3), the Illinois No. 6 slag formed a solid brown glassy deposit completely covering each test sample. X-ray diffraction analysis of the gasified slag showed it to be predominantly amorphous. However, microprobe analysis revealed the microstructure of the slag to be a 


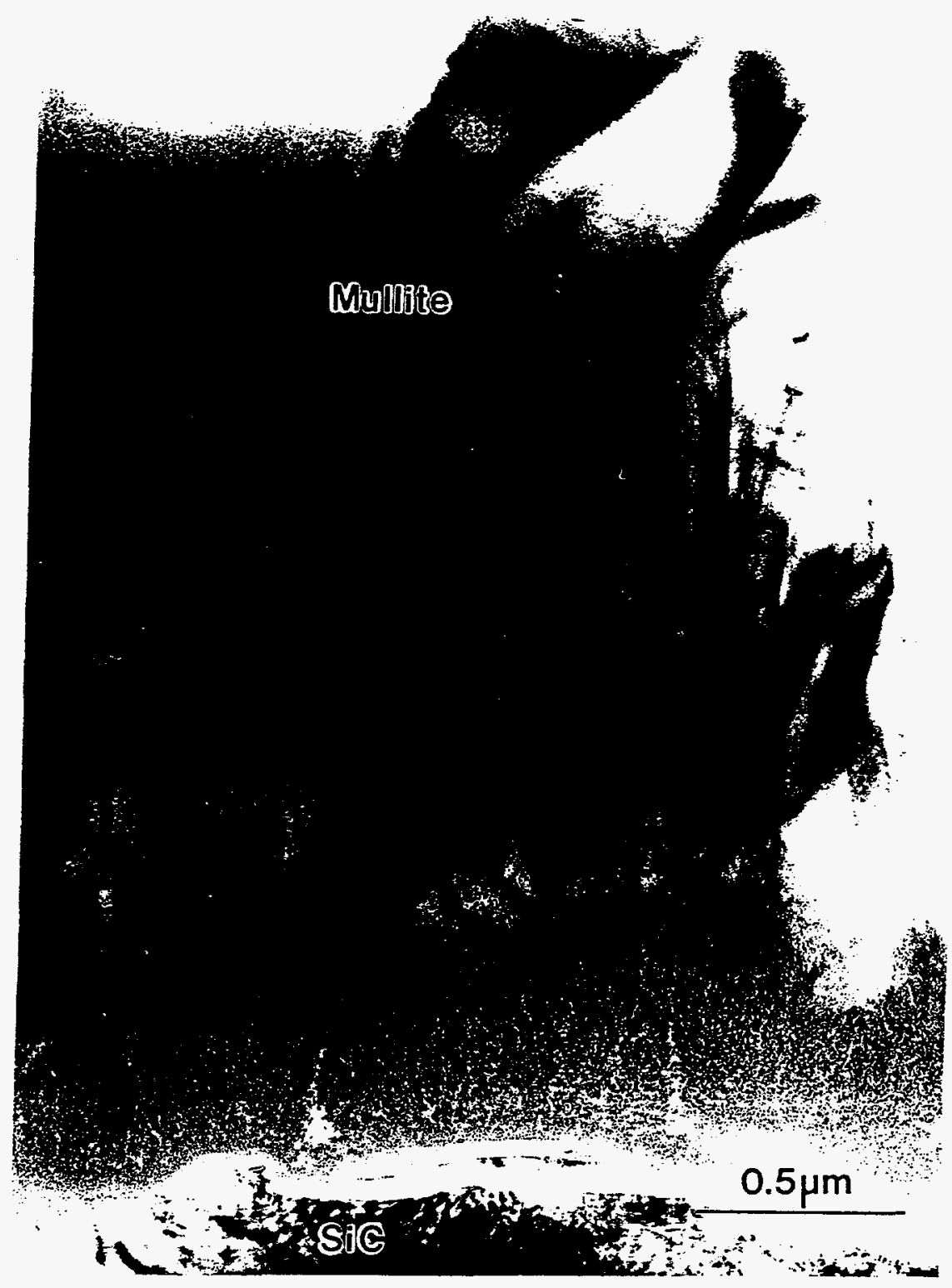

Figure 9: A typical TEM morphology of the CVD mullite coating on SiC 


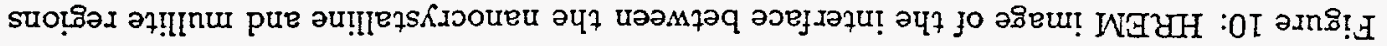

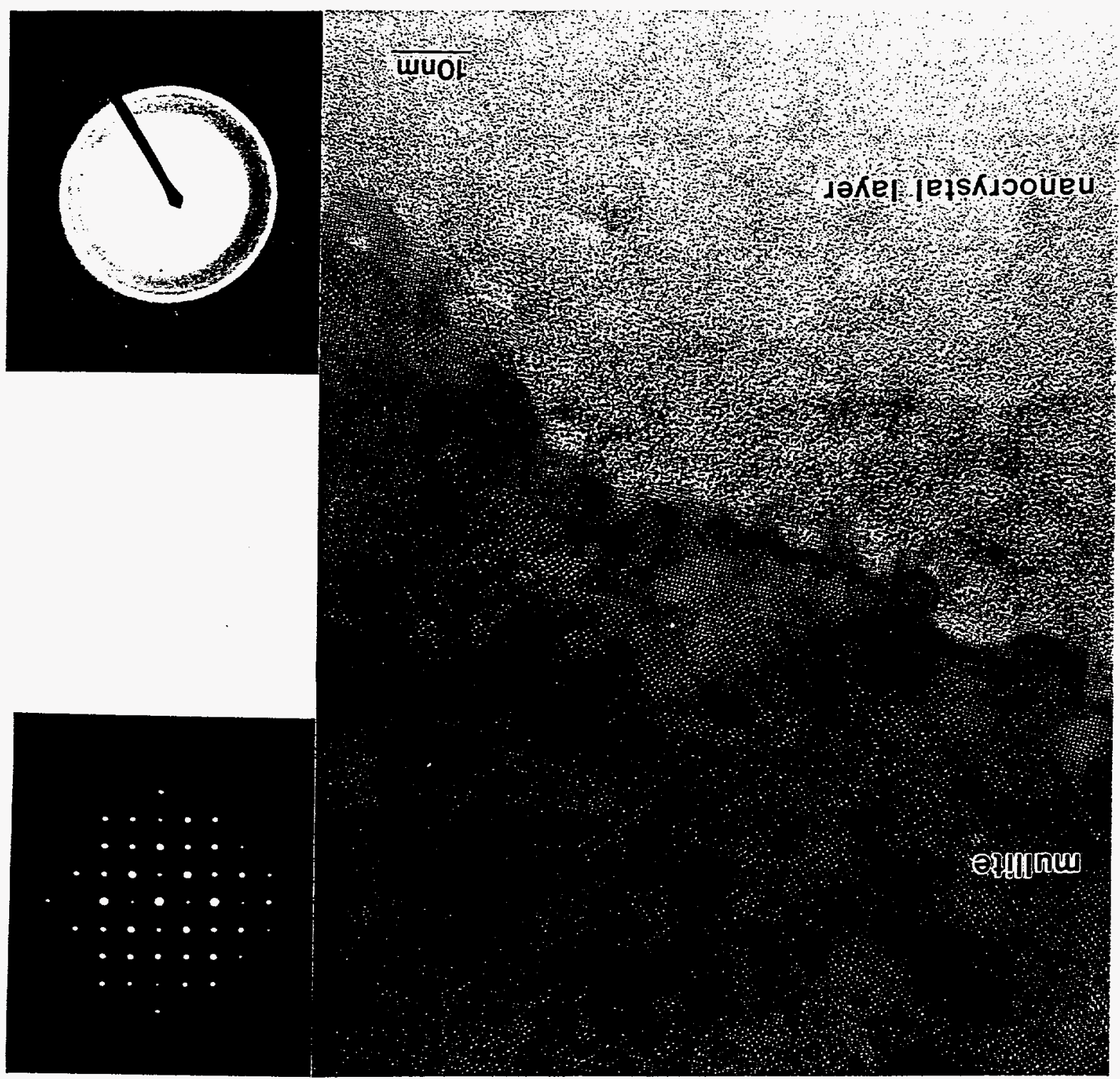




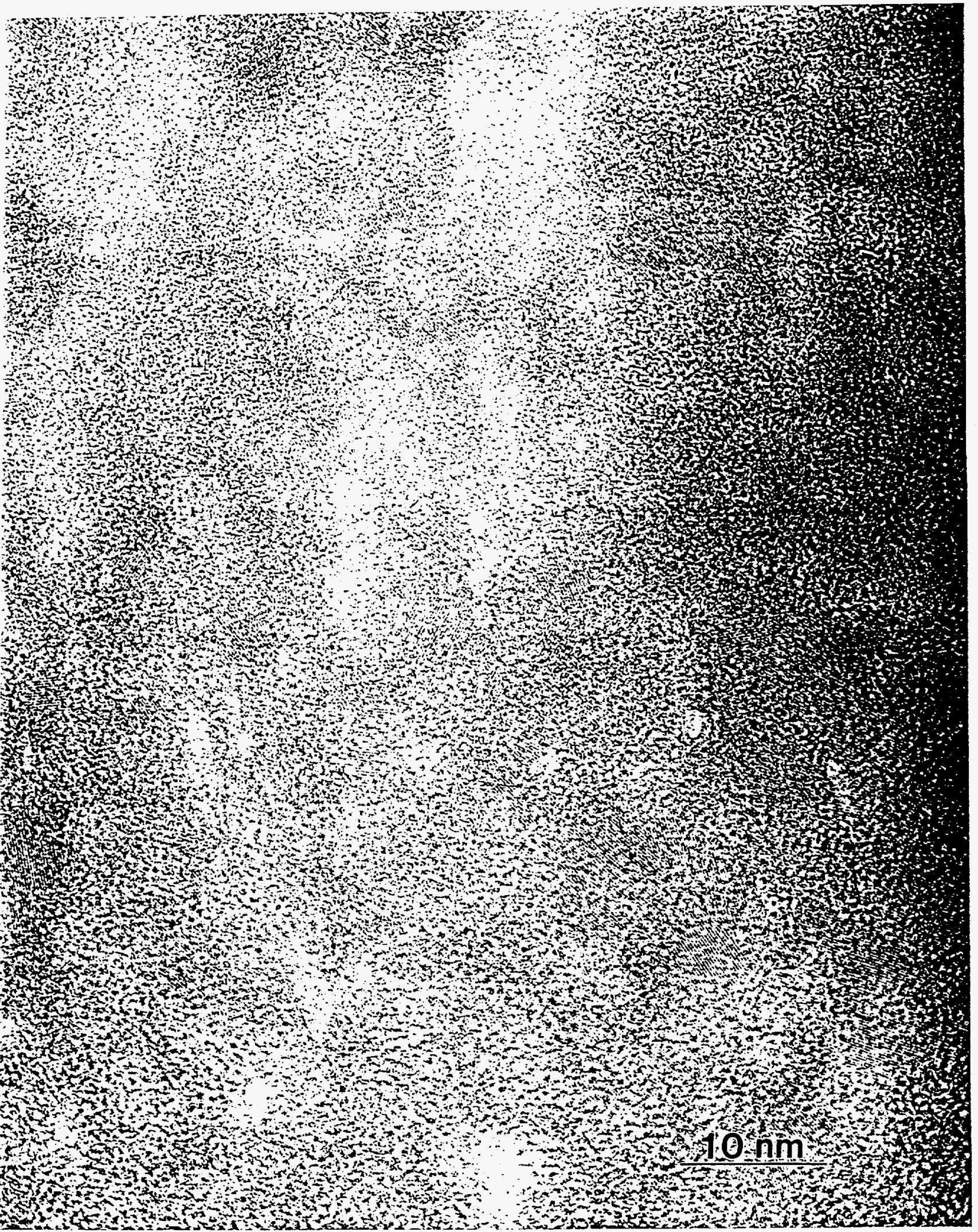

Figure 11: HREM of the nanocrystalline region 


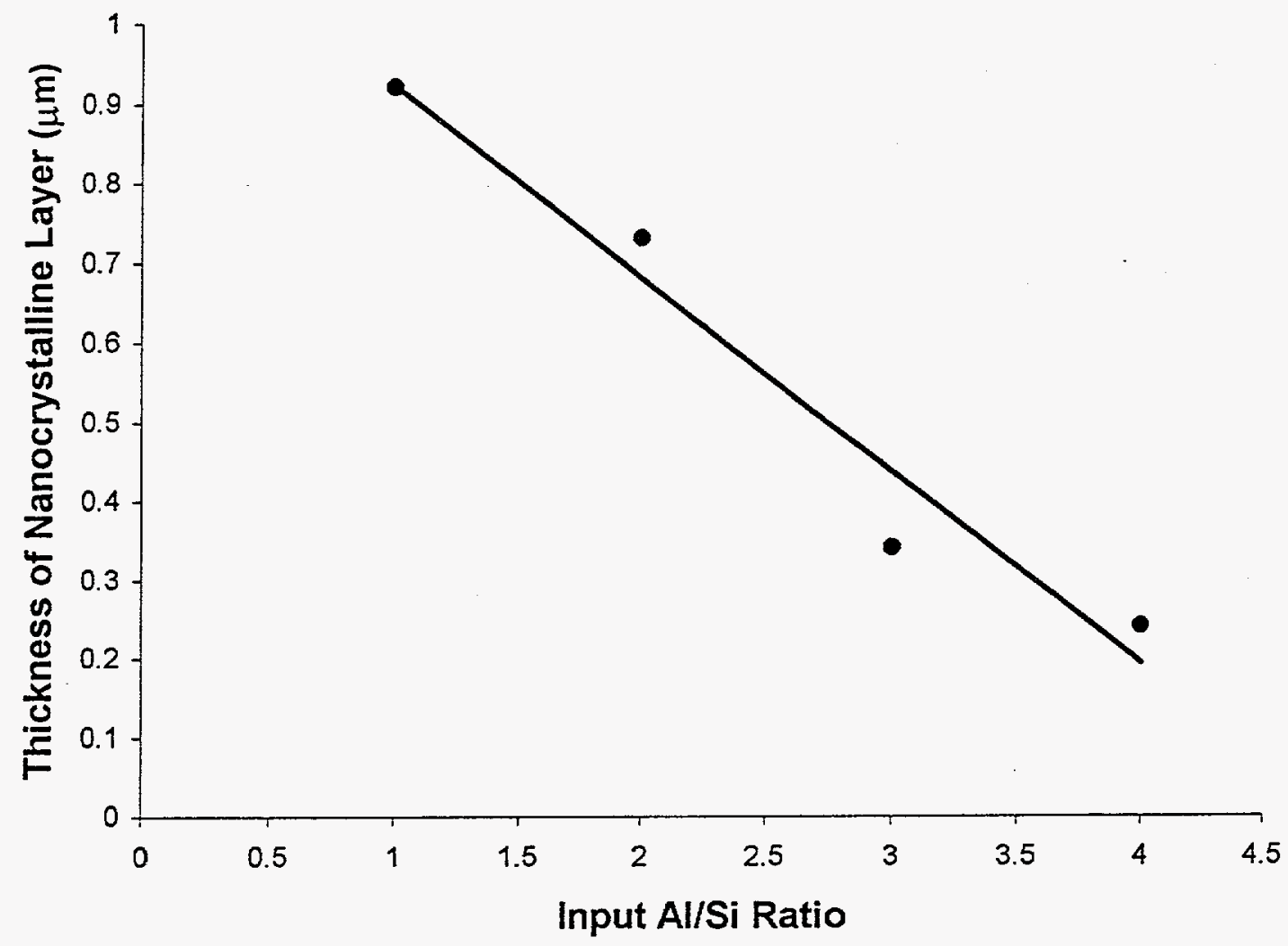

Figure 12: Thickness dependence of the nanocrystalline layer on the input $\mathrm{AlCl}_{3} / \mathrm{SiCl}_{4}$ ratio 


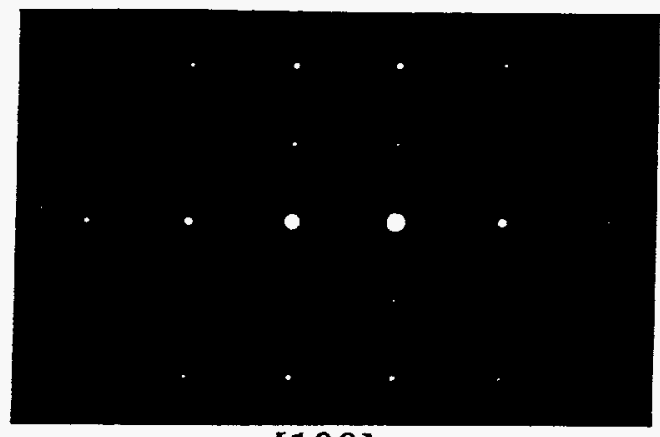

[100]
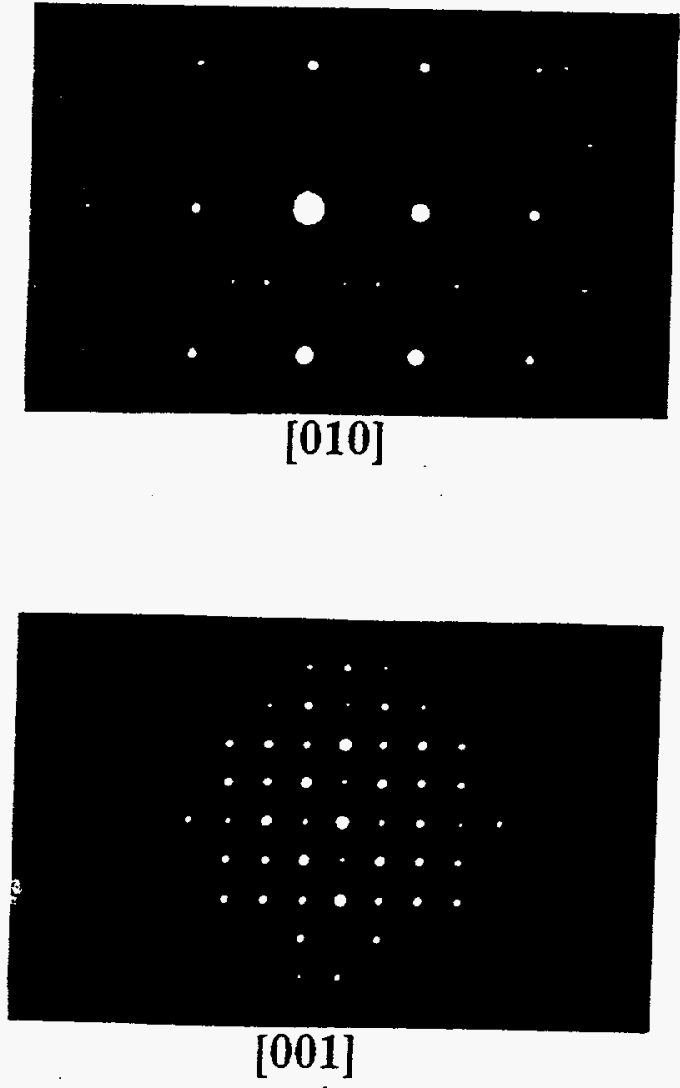

Figure 13: Electron diffraction pattern of crystalline mullite along main zone axes 

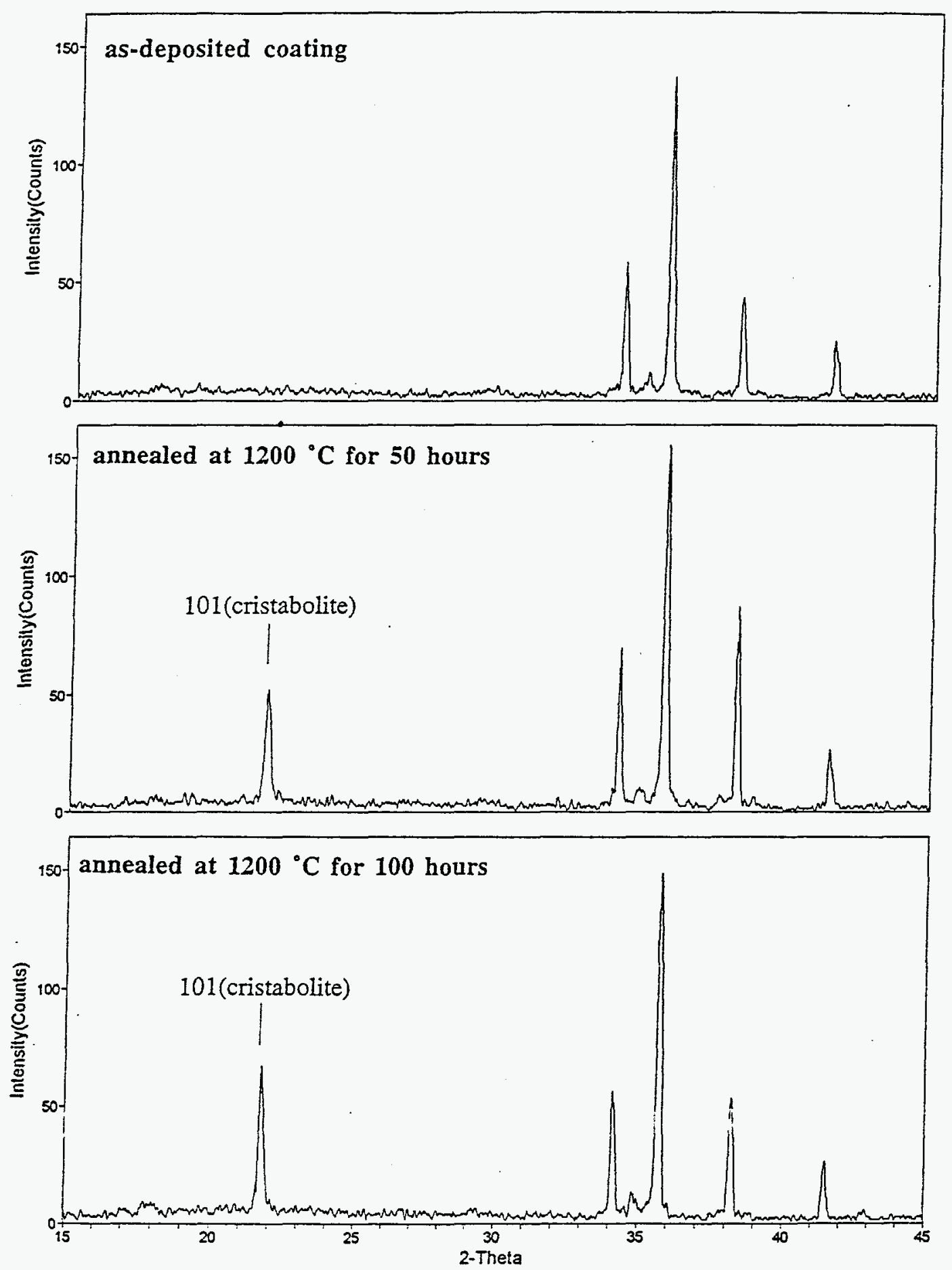

Figure 14: Phase transformation of the nanocrystalline layer after annealing at $1200^{\circ} \mathrm{C}$ for 100 hours 

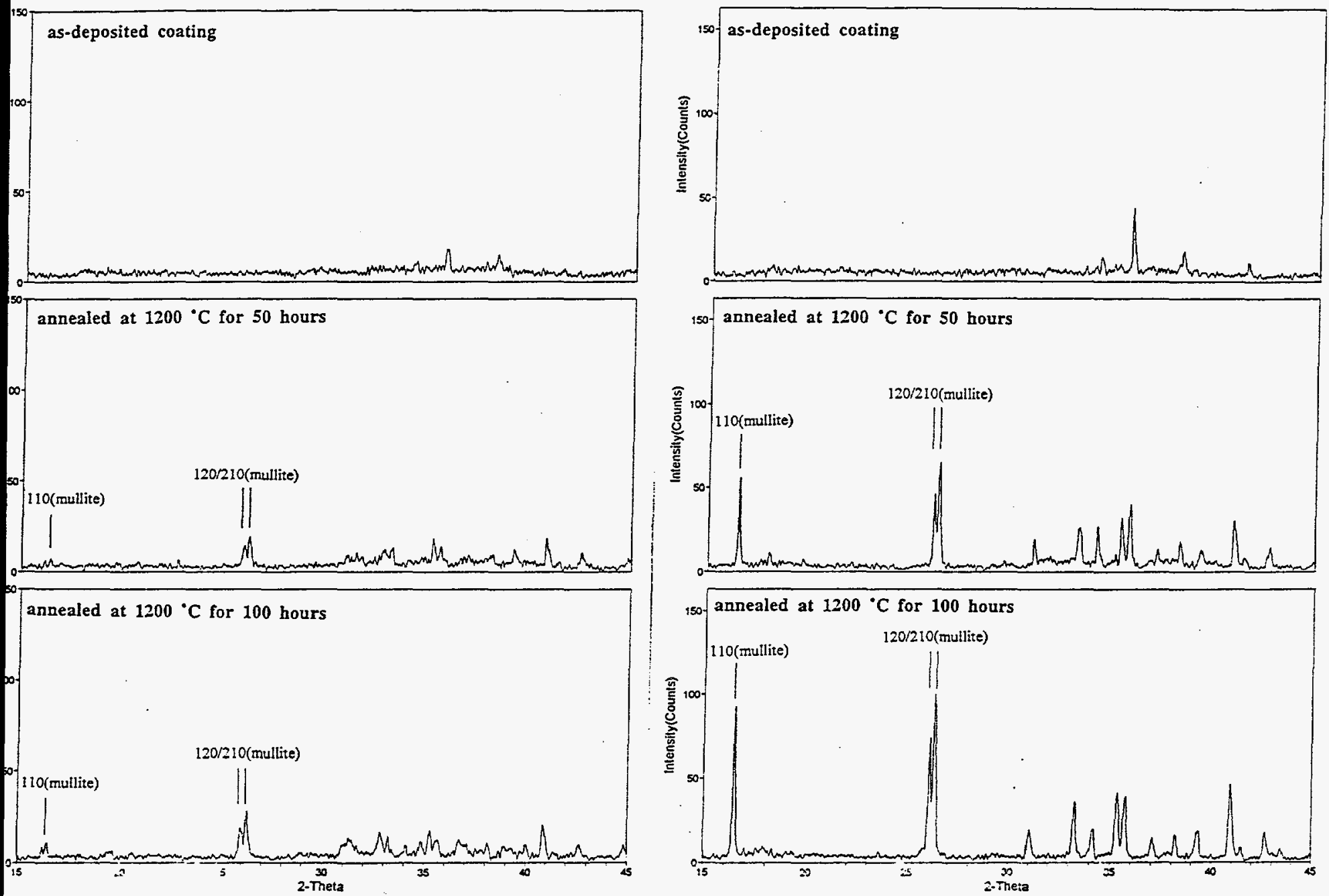

(a)

(b)

Figure 15: Phase transformation of the nanocrystalline layer with extra Al available (a) a Al rich layer on top of the nanocrystalline layer, (b) a Al rich layer between the substrate and the nanocrystalline layer 


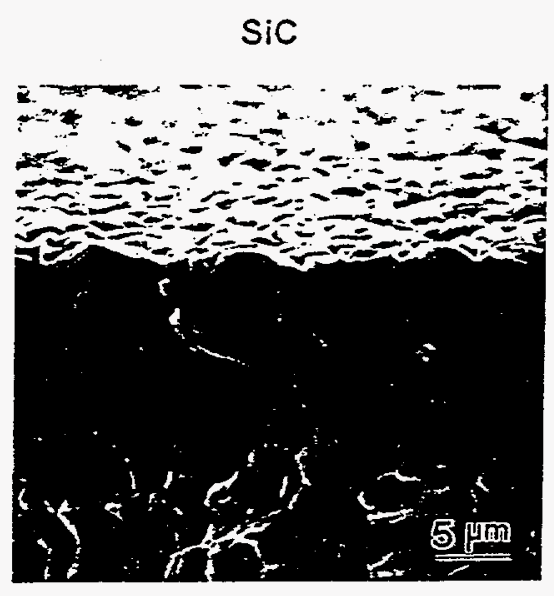

$\mathrm{Al}_{2} \mathrm{O}_{3}$

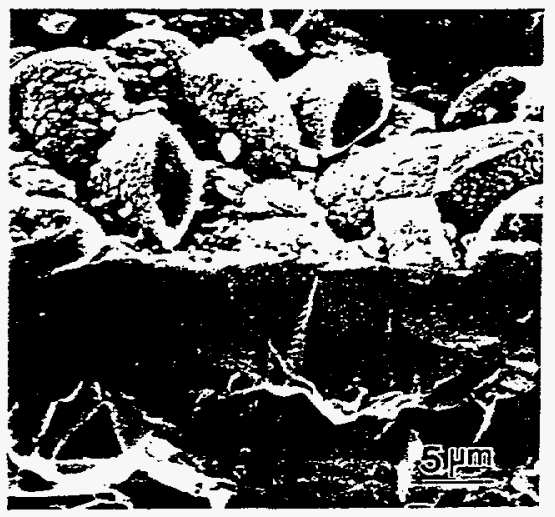

Mullite

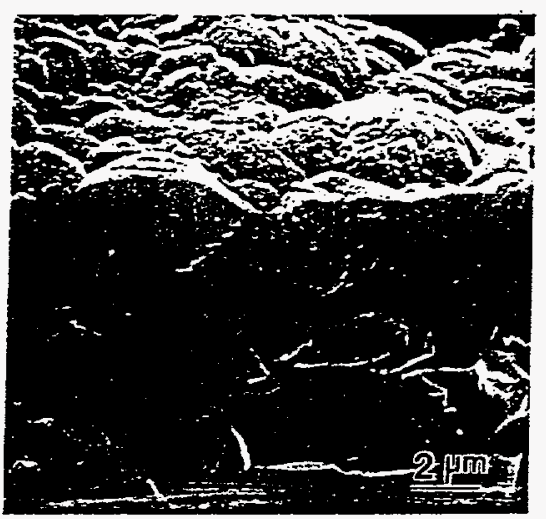

Figure 16: Cross-section of mullite coatings grown on a) SiC, b)Alumina, c)mullite 
mixture of crystallites and glass. Figure 17 and Table 2 illustrate the differing compositions and appearance of the glass and crystal particles that compose the post-exposure slag matrix. Further analysis into the composition of the molten slag has been discussed by other investigators [26]. Microprobe analysis suggests that the principle crystalline phase of the slag is anorthite $\left(\mathrm{CaO} \cdot \mathrm{Al}_{2} \mathrm{O}_{3} \cdot 2 \mathrm{SiO}_{2}\right)$ [27]. Microprobe analysis also revealed trace quantities of vanadium contamination within the slag. Vanadium is not a component of the burnt coal ash but a component of a fuel oil used in the gasification process [26]

\subsection{Corrosion of $\mathrm{Al}_{2} \mathrm{O}_{3}$}

Figure 18a is an electron micrograph of the interface between $\mathrm{Al}_{2} \mathrm{O}_{3}$ and Illinois No. 6 slag after Test 1. The interface between the slag and the $\mathrm{Al}_{2} \mathrm{O}_{3}$ indicates that a corrosion product has formed at the interface. This corrosion product is believed to be the spinel hercynite $(\mathrm{Fe}, \mathrm{Mg}) \mathrm{O} \cdot(\mathrm{Al}, \mathrm{Fe})_{2} \mathrm{O}_{3}$. This diffusional phase is $\approx 7 \mu \mathrm{m}$ thick and has been observed by other researchers when $\mathrm{Al}_{2} \mathrm{O}_{3}$-based ceramics are exposed to coal slag [27]. This corrosion product may act as a diffusional barrier to further corrosion yet, significant cracking of the substrate did occur presumably due to the large CTE of $\mathrm{Al}_{2} \mathrm{O}_{3}$. These exact results were also observed after Tests 2-4.

\subsection{Corrosion of Mullite Substrate}

The bulk mullite sample showed no signs of corrosion or pit formation during Tests 1-4. The electron micrograph results from Test 1 show a clean and tightly bonded corrosion interface between the mullite and slag layer (Figure 19). A compositional difference is observed in the coal slag as illustrated in the Fe dot map, yet this diffusional phase has not appreciably degraded the mullite sample and no cracking was observed.

The slag did have a strong bond with the alumina and mullite substrates. $\mathrm{Al}_{2} \mathrm{O}_{3}$ and slag seemed to have formed the spinel phase hercynite, $(\mathrm{Fe}, \mathrm{Mg}) \mathrm{O} \cdot(\mathrm{Al}, \mathrm{Fe})_{2} \mathrm{O}_{3}$, at the slag-ceramic interface [27]. It appears in Figure 19 that the bulk mullite sample acted as a nucleation site for the coal slag's crystallization to anorthite yet degradation of the mullite sample is not evident. Although alumina offered excellent slag corrosion resistance, it is limited as a coal gasification heat exchanger material to due its low thermal conductivity and susceptibility to thermal shock induced cracks and material failure. The calculated thermal 


\begin{tabular}{|l|l|l|l|}
\hline & Fe & Si & C \\
\hline \hline Fe Corrosion Area & At \% & At \% & At \% \\
\hline $\mathrm{Fe}_{3} \mathrm{Si}$ & 74.1 & 25.9 & 0.0 \\
\hline $\mathrm{Fe}_{5} \mathrm{Si}_{3}$ & 63.3 & 36.7 & 0.0 \\
\hline Graphite Corrosion Area & 0.05 & 0.01 & 99.2 \\
\hline
\end{tabular}

Table 6: Microprobe analysis of the 2-phase iron silicide corrosion product at the SiC-slag interface

stress experienced by the alumina substrates in Tests 1-4 was greater than the maximum allowable tensile strength. In addition, alumina is not a suitable $\mathrm{SiC}$ protective coating material as its CTE is almost twice as great as SiC's CTE (Table 8). The solid mullite sample's effectiveness as a potential heat exchanger material is limited by its extreme porosity and compositional inhomogeneities (Table 1).

\subsection{Corrosion of $\mathrm{SiC}$}

After 300 hours of exposure to coal slag at $1260^{\circ} \mathrm{C}$ in Test 1 , the uncoated $\mathrm{SiC}$ sample was severely corroded (Figure 20a). Optical and scanning electron microscopy revealed slag corrosion characterized by pit formation and subsequent material loss. Pit depths ranged from 44 to $284 \mu \mathrm{m}$ with an average pit depth of $126 \mu \mathrm{m}$ into the substrate (Figure 24). The entire interface between the slag and $\mathrm{SiC}$ substrate was corroded leaving no clean unaffected areas. The pit formation within the $\mathrm{SiC}$ substrate was characterized by white and black corrosion regions (Figure 21a). EDS analysis revealed the white region to have a high iron content and the black region to have a high carbon content. The Fe dot maps and SEM micrographs show that the high iron corrosion areas surround the corrosion pits and have a dense white appearance (Figure 21). The high carbon region is typically found at the center of the corrosion pit and has a dark flaky appearance. Further analysis of the corrosion pit utilizing microprobe analysis indicated the high carbon region to be graphite and the high iron region to consist of two phases of iron silicides (Table 6). Based on the quantitative elemental compositional data found from the microprobe analysis of a corrosion pit, the two phases of iron silicides formed were $\mathrm{Fe}_{3} \mathrm{Si}$ and $\mathrm{Fe}_{5} \mathrm{Si}_{3}$.

The corrosion rate constants in Table 7 are calculated according to a parabolic diffusion mechanism given in Eqn. 4 where $X$ is corrosion depth, $K_{p}$ is the parabolic constant, and $t$ is exposure time [37].

$$
X^{2}=2 K_{p} t
$$




\begin{tabular}{|l|l|l|l|l|}
\hline Time (hr) & SiC & $\begin{array}{l}\text { Bulk } \\
\text { Mullite }\end{array}$ & $\begin{array}{l}\text { CVD } \\
\text { Mullite \#1 }\end{array}$ & $\begin{array}{l}\text { CVD } \\
\text { Mullite \#2 }\end{array}$ \\
\hline \hline 10 & 13.3 & 0 & 0 & 0 \\
\hline 20 & 17 & 0 & 1.9 & 0 \\
\hline 40 & 23.75 & 0 & - & 0 \\
\hline 300 & 126 & 0 & 7.6 & - \\
\hline$K_{p}\left(\mu \mathrm{m}^{2} / \mathrm{hr}\right)$ & 27.9 & 0 & 0.098 & 0 \\
\hline
\end{tabular}

Table 7: Average slag pitting depth and parabolic corrosion rate constant

Previous research conducted on Illinois No.6 slag and siliconized $\mathrm{SiC}$ interaction, reported the formation of graphite and a single phase iron silicide shown below in Eqn. 5 [38].

$$
\begin{aligned}
2 \mathrm{SiC}+\mathrm{Si}+\mathrm{Fe}_{2} \mathrm{O}_{3} & \rightarrow 2 \mathrm{FeSi}+\mathrm{SiO} \mathrm{O}_{2}+\mathrm{CO}+\mathrm{C} \\
\Delta G & =-470.3 \mathrm{~kJ} / \mathrm{mol}\left(1227^{\circ} \mathrm{C}\right)
\end{aligned}
$$

The formation of the single phase iron silicide, $\mathrm{FeSi}$, and graphite was also predicted as the equilibrium corrosion products by the thermodynamic modelling program SOLGAS as shown in Eqn.6.

$$
\begin{aligned}
2 \mathrm{SiC}+\mathrm{Fe}_{2} \mathrm{O}_{3} & \rightarrow \frac{3}{2} \mathrm{Fe}+\frac{1}{2} \mathrm{FeSi}+\frac{3}{2} \mathrm{SiO}+2 \mathrm{C} \\
\Delta G & =-495.6 \mathrm{~kJ} / \mathrm{mol}\left(1260^{\circ} \mathrm{C}\right)
\end{aligned}
$$

Microprobe and SEM analysis revealed, however, the presence of two phases of iron silicide that were not projected by the thermodynamic simulations due to the lack of thermodynamic data on these phases (Figure 22). The iron silicides were characterized as $\mathrm{Fe}_{3} \mathrm{Si}(75 \% \mathrm{Fe}$ and $25 \% \mathrm{Si})$ and $\mathrm{Fe}_{5} \mathrm{Si}_{3}(63 \% \mathrm{Fe}$ and $37 \% \mathrm{Si})$ (Table 6). Equilibrium diagrams of the $\mathrm{Fe}-\mathrm{Si}$ system show that $\mathrm{Fe}_{5} \mathrm{Si}_{3}$ and $\mathrm{Fe}_{3} \mathrm{Si}$ are thermodynamically stable products at the coal slag reaction conditions of Tests 1-4 [39]. $\mathrm{Fe}_{3} \mathrm{Si}$ is an $\alpha$-phase with a wide solubility and $\mathrm{Fe}_{5} \mathrm{Si}_{3}$ is a line compound. Equation 7 illustrates a possible reaction between the slag and $\mathrm{SiC}$ in Tests $1-4$.

$$
9 \mathrm{SiC}+4 \mathrm{Fe}_{2} \mathrm{O}_{3} \rightarrow \mathrm{Fe}_{3} \mathrm{Si}+\mathrm{Fe}_{5} \mathrm{Si}_{3}+5 \mathrm{SiO}_{2}+7 \mathrm{C}+2 \mathrm{CO}
$$

The two phase nature of the slag corrosion reaction was not predicted by SOLGAS as the phases are not in the programs database. There is currently no thermodynamic curve fit data in existence for $\mathrm{Fe}_{5} \mathrm{Si}_{3}$ and $\mathrm{Fe}_{3} \mathrm{Si}$ within the temperature range of interest. 
Uncoated $\mathrm{SiC}$ is not a suitable coal gasification heat exchanger material as it experienced severe corrosion and material loss after only 300 hours of exposure.

\subsection{Corrosion of CVD Mullite Coated SiC}

The CVD mullite coated SiC substrate exhibited excellent coal slag corrosion protection after 300 hours of exposure in Test 1(Figure 20b). The corrosion interface was predominantly clean along the length of the coating with sparse pitting in some areas ranging from $1.9-17.1$ microns with an average pit depth of 7.6 microns. EDS analysis and $\mathrm{Al}, \mathrm{Fe}$, and $\mathrm{Si}$ dot maps show the presence of an intact $\mathrm{CVD}$ mullite coating which is unaffected by the presence of molten slag after 300 hours of exposure. The coating region is characterized by high concentrations of $\mathrm{Al}, \mathrm{Si}$, and $\mathrm{O}$ (Figure 23). The mullite coating acted as a barrier to the slag penetration. Microprobe analysis of the mullite coating/slag interface after Test 1 showed the formation of a stable $\mathrm{Fe}(\mathrm{Mg}) \mathrm{Al}_{2} \mathrm{O}_{4}$ spinel phase. This spinel phase has been shown to form in certain $\mathrm{Al}_{2} \mathrm{O}_{3}$ composites (Figure 18) and has been predicted to act as a diffusion barrier to further coal slag attack of the ceramic surface [27]. The CVD mullite SiC substrates had clean non-pitted corrosion interfaces in all regions with a uniform coating.

CVD mullite coatings protect SiC from coal slag corrosion. Altering the mullite deposition parameters affects the resultant coating growth rate, morphology, and crystal structure. Preliminary results reveal that uniform coatings (CVD mullite \#2) completely protect the SiC surface from corrosion (Figure 23 \& Table 7). A $300 \mathrm{hr}$ test is currently being run on CVD mullite \#2. The CVD mullite coated SiC samples tested had corrosion rates ranging from $0-0.0983 \mu \mathrm{m}^{2} / \mathrm{hr}$.

The formation of the $\mathrm{Fe}(\mathrm{Mg}) \mathrm{Al}_{2} \mathrm{O}_{4}$ spinel phase at the surface of the CVD mullite sample in Test 1 has been predicted for certain $\mathrm{Al}_{2} \mathrm{O}_{3}$ composites. The top surface of CVD mullite coatings on $\mathrm{SiC}$ are $\mathrm{Al}_{2} \mathrm{O}_{3}$-rich making it possible for a similar reaction to take place [30]. The formation of such a spinel reaction layer has been theoretically predicted under similar conditions when the slag concentration contains $\approx 10 \% \mathrm{MgO}$. Microprobe analysis of the coal slag at the CVD mullite surface indicated that the $\mathrm{MgO}$ content was $9.9 \%$. The spinel reaction layer formed has also been shown to act as a diffusion barrier to corrosive coal slag [40].

Calculation of the stress magnitude caused by the expansion mismatch between the slag-ceramic may 


\begin{tabular}{|l|l|l|l|l|l|}
\hline & $\mathrm{E} \times 10^{6}$ & $\mathrm{CTE}$ & $\mu$ & $\sigma$ & Tensile Strength \\
\hline & $(\mathrm{psi})$ & $\left(\times 10^{6}\right)$ & & $(\mathrm{MPa})$ & $(\mathrm{MPa})$ \\
\hline \hline $\mathrm{Slag}$ & 11 & 4 & 0.25 & & \\
\hline $\mathrm{SiC}$ & 59 & 4.7 & 0.14 & -45 & 138 \\
\hline $\mathrm{Al}_{2} \mathrm{O}_{3}$ & 51 & 8.1 & 0.21 & -283 & 255 \\
\hline $\mathrm{Mullite}$ & 16 & 5.05 & 0.23 & -58 & 110 \\
\hline CVD Mullite & 16 & 5.05 & 0.23 & -185 & \\
\hline
\end{tabular}

Table 8: Stress in selected materials caused by thermal expansion mismatch with the coal slag.

explain the localized failure exhibited by some CVD mullite coatings. The slag properties given in Table 8 are estimated from a typical aluminosilicate glass. The stress caused by the coal slag $(\sigma)$ can be estimated from Eqn.8.

$$
\sigma=\frac{E_{\text {slag }}\left(\alpha_{\text {slag }}-\alpha\right)(\Delta T)}{1+\frac{2 E_{\text {slag }} t_{\text {slag }}}{E t} \times \frac{1}{1-\mu}}
$$

\section{Conclusions}

Current studies have focused upon the development of CVD mullite coatings for corrosive environments. Thermodynamic and kinetic investigations have resulted in uniform, stable, and protective coatings. CVD mullite coatings are deposited within a kinetically limited regime. The substrate is extremely important in determining the initial nucleation of the deposit, and thus the ultimate structure and morphology of the coating.

Thermal studies reveal that mullite is stable in high temperature environments $\left(>1260^{\circ} \mathrm{C}\right)$. A crystallization of the nano-crystalline layer occurs when there is excess $\mathrm{Al}$ present. Analysis of the structure indicates that tetragonal mullite is deposited within areas of the coating. CVD mullite coated SiC exhibited excellent coal slag corrosion resistance after 300 hours of exposure to an acidic iron based Illinois No. 6 slag. The CVD mullite coating's performance was dependent on the coating's microstructure and uniformity. CVD mullite coating protection was based on its function as a diffusion barrier to iron penetration and a physical barrier to liquid slag seepage into the $\mathrm{SiC}$ substrate. The uncoated $\mathrm{SiC}$ suffered severe material loss and pitting due to coal slag corrosion. The corrasion of the $\mathrm{SiC}$ was based on the formation of two phase iron silicides $\left(\mathrm{Fe}_{x} \mathrm{Si}_{y}\right)$ and graphite within the $\mathrm{SiC}$ replacing the substrate material. The uncoated $\mathrm{SiC}$ exhibited 


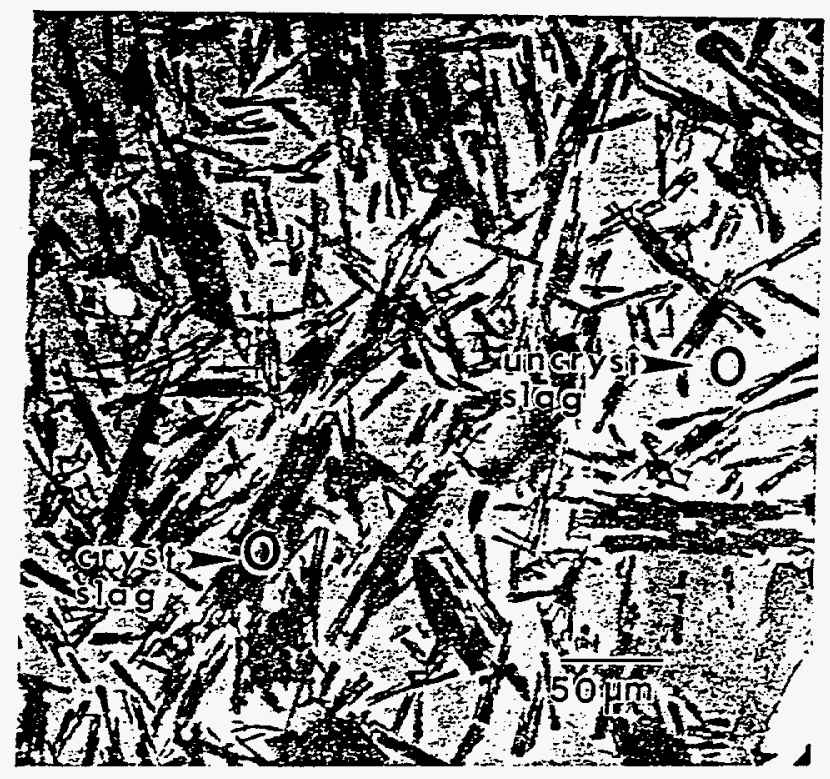

Figure 17: Microprobe micrograph of Illinois No.6 coal slag from Test 1. Crystallites are anorthite. 

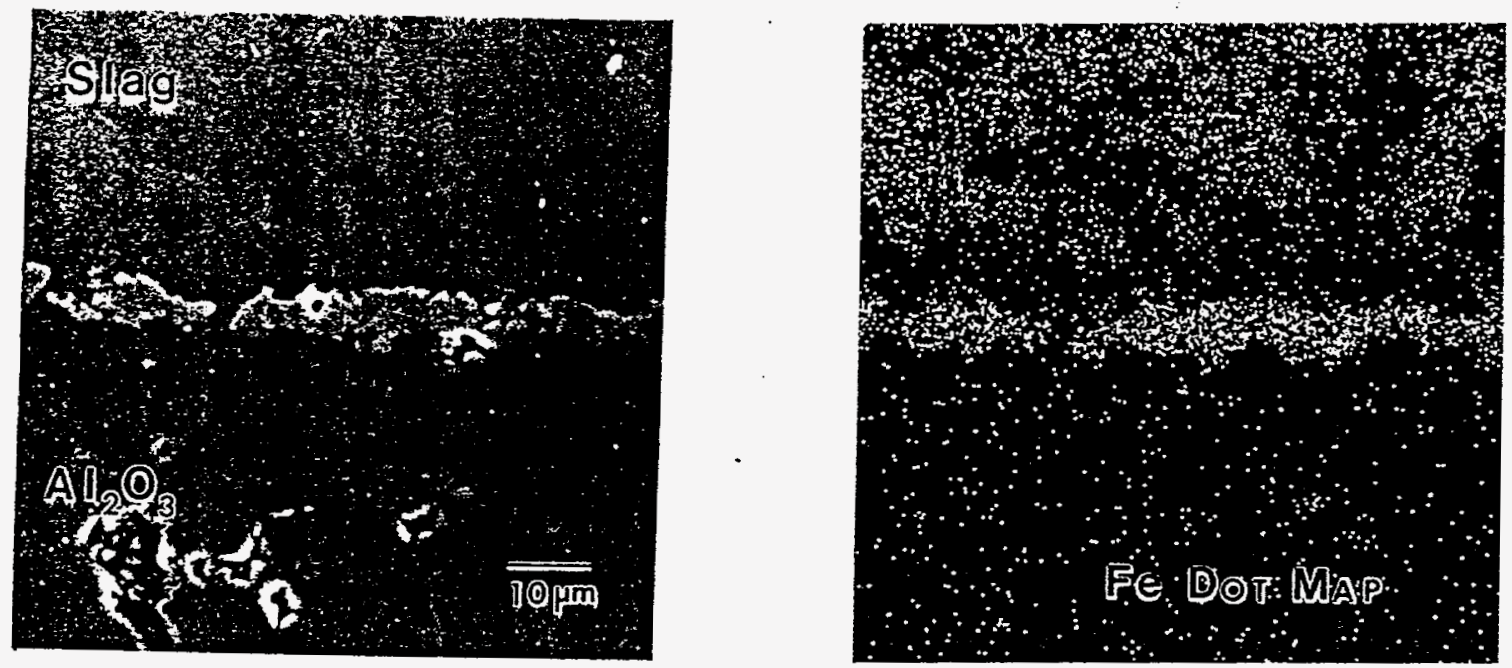

Figure 18: Scanning electron micrograph of (a) alumina/slag interface from Test 1, 1000x, (b) Fe dot map highlighting corrosion product at interface 

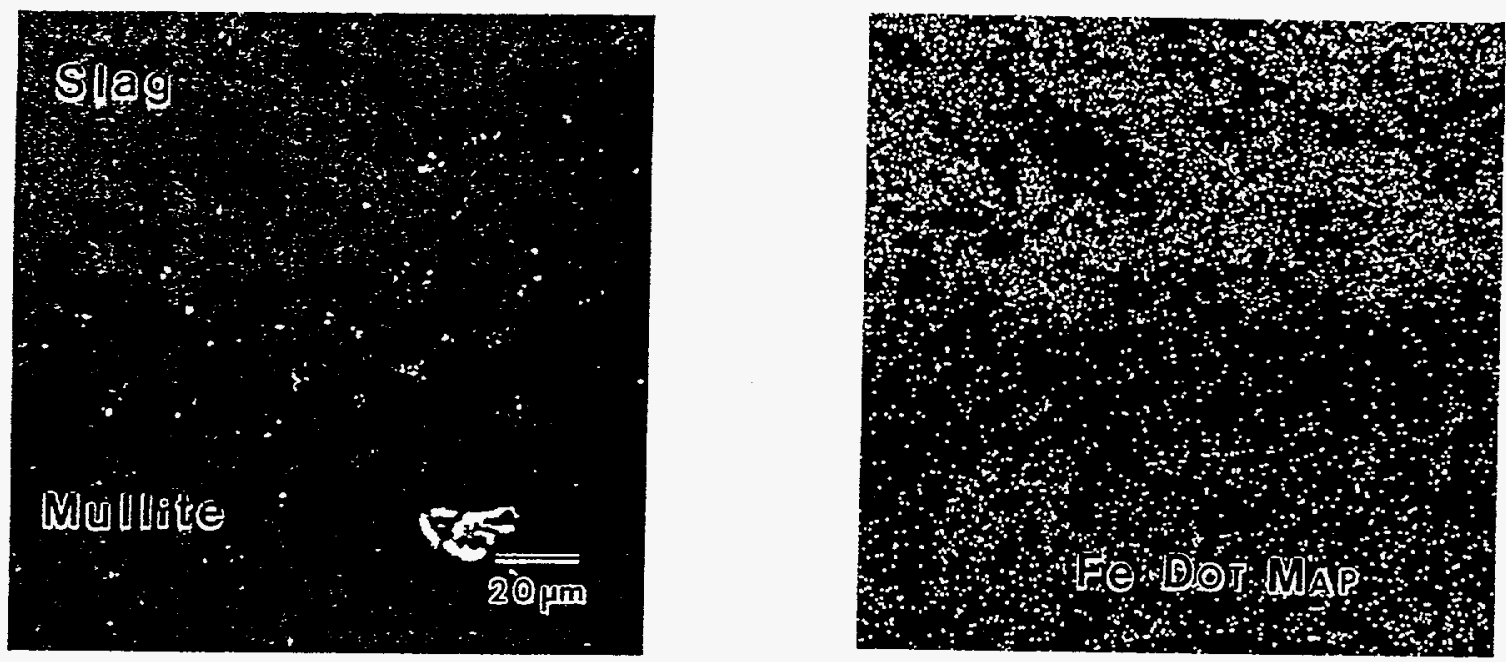

Figure 19: Scanning electron micrograph of (a) bulk mullite/slag interface from Test 1, 500x, (b) Fe dot map at interface 

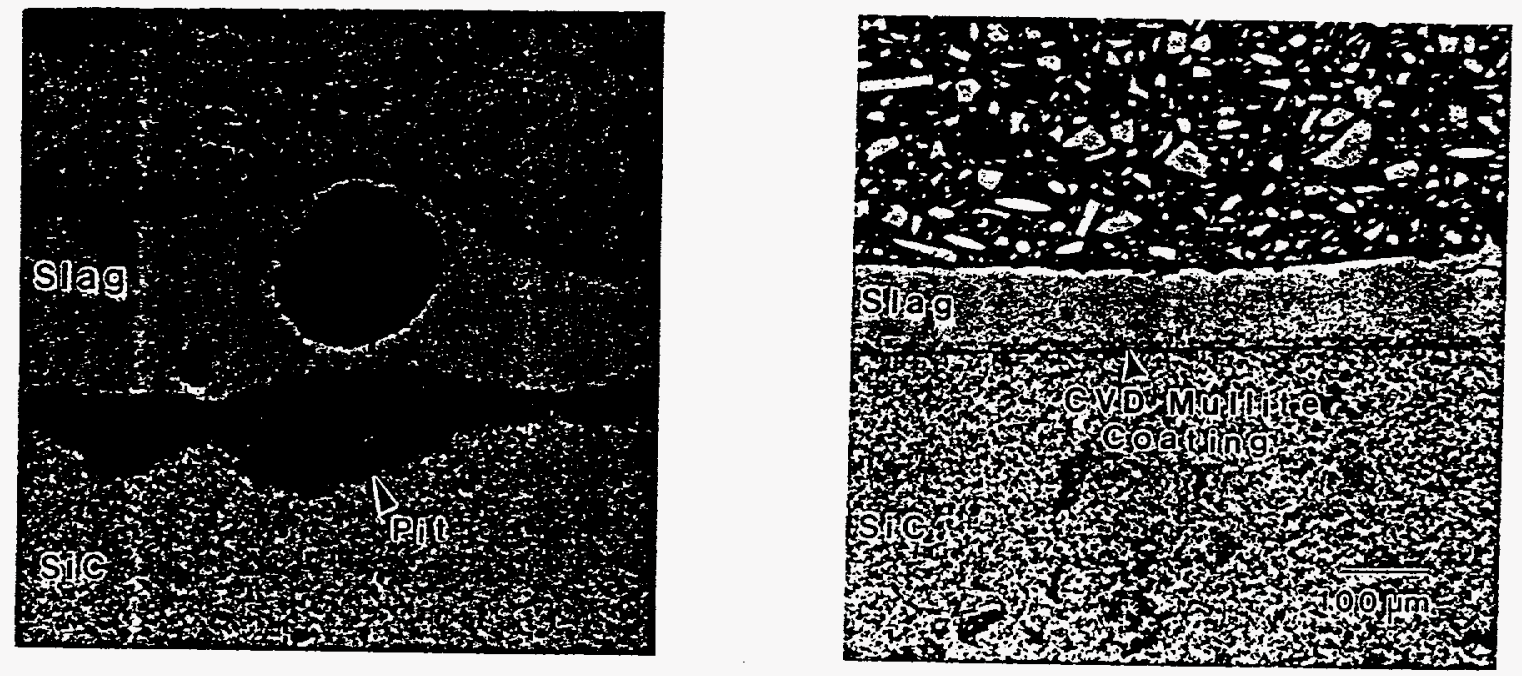

Figure 20: Optical micrographs of from Test 1: (a) Uncoated SiC corrosion interface, 100x, (b) CVD mullite coated $\mathrm{SiC}$ corrosion interface $100 \mathrm{x}$. 

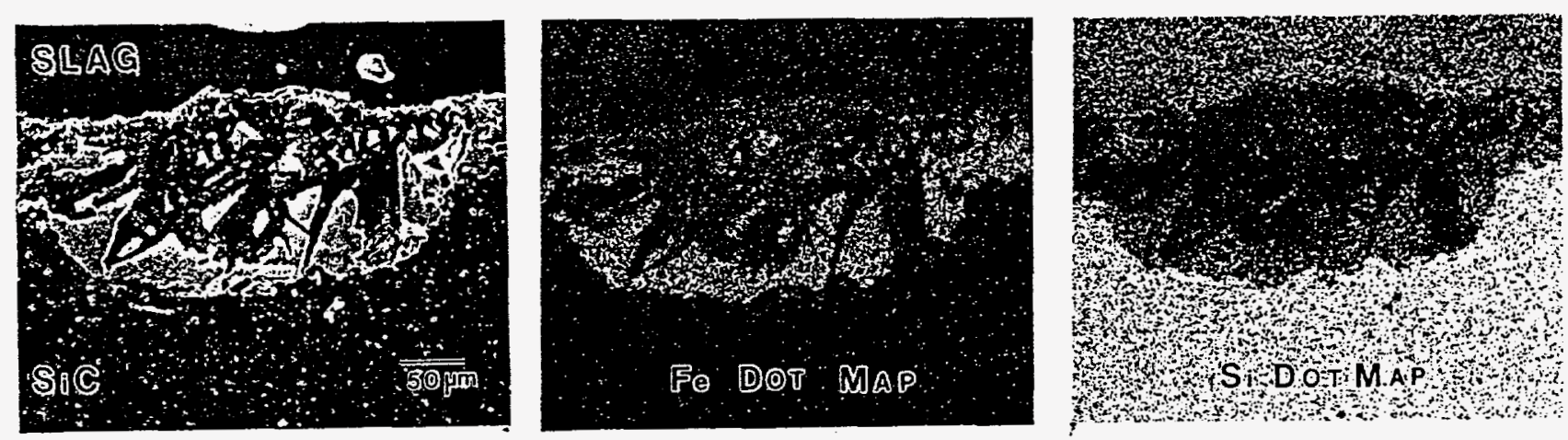

Figure 21: Uncoated $\mathrm{SiC}$ corrosion pit from Test1: (a) SEM micrograph, 200x, (b) Fe dot map dot map(c) Si dot map 


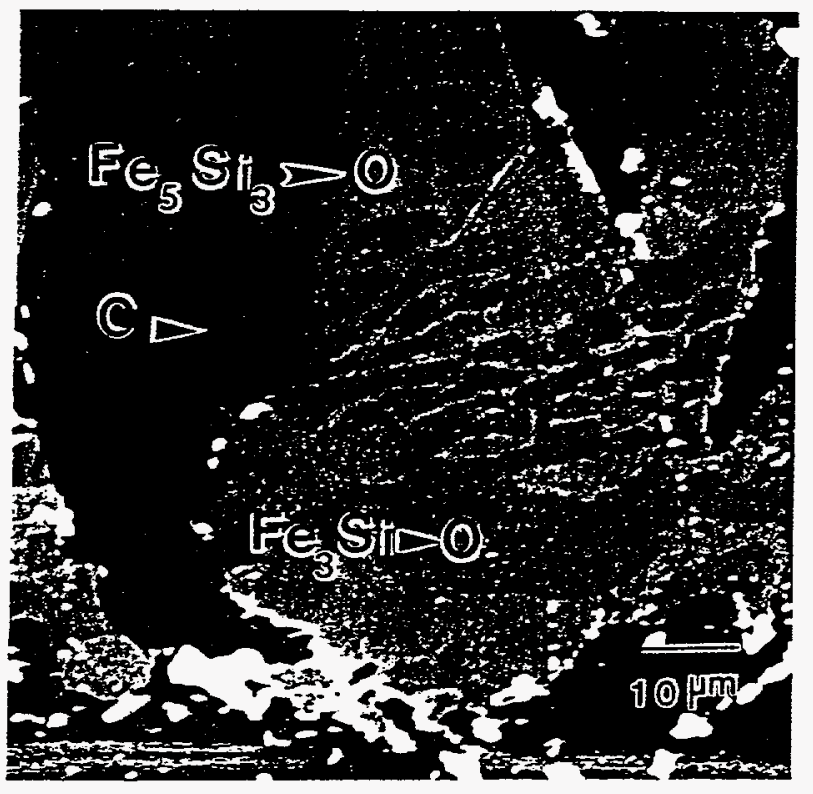

Figure 22: Optical micrograph of 2-phase iron silicide corrosion region from Test1. 

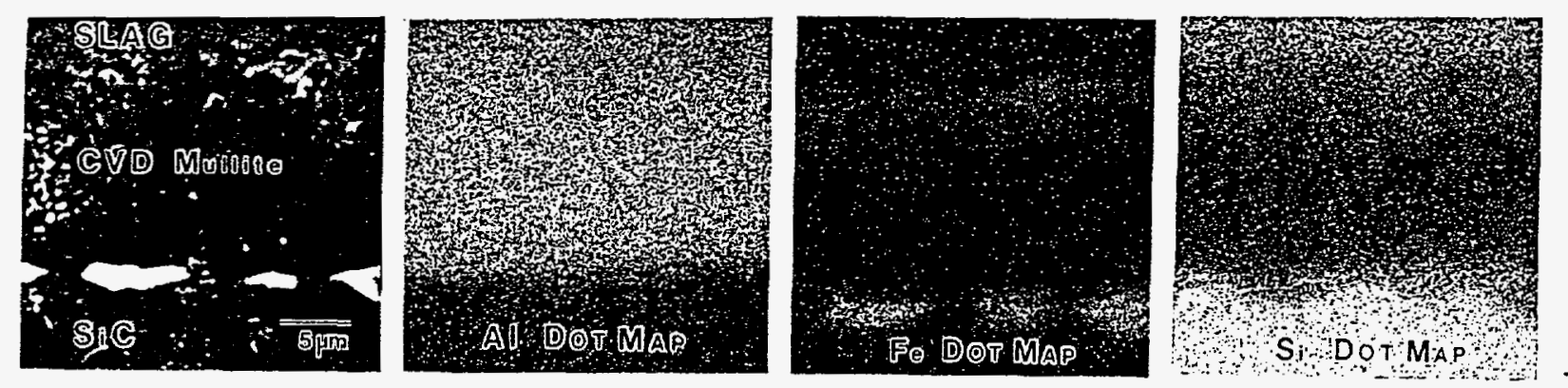

Figure 23: CVD mullite coating region from Test1: (a)SEM of slag/mullite/coating interfaces, 2500X (b) Al dot map, (c) Fe dot map, (d) Si dot map. 


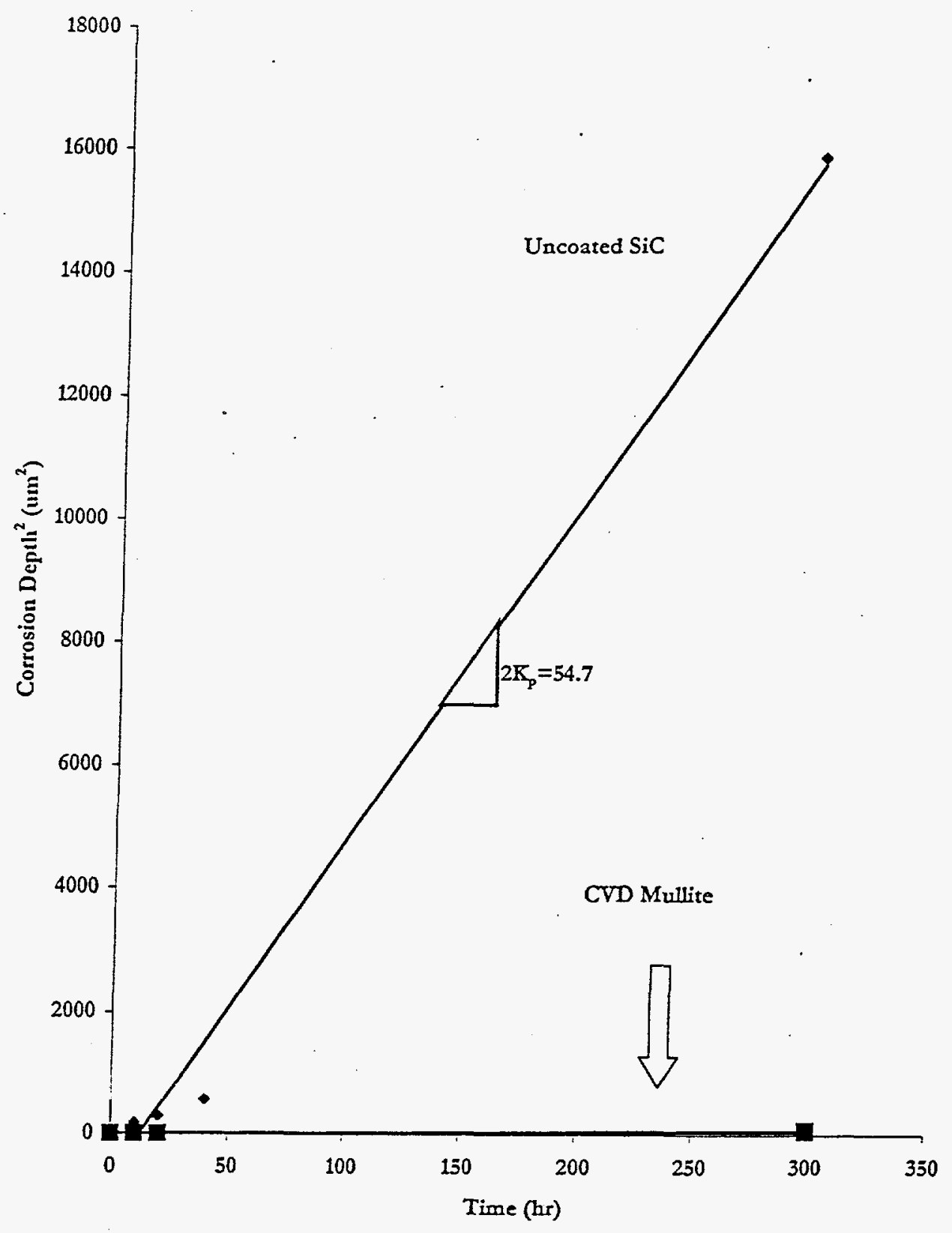

Figure 24: Comparison of corrosion rates of Coated and Uncoated SiC 
a corrosion rate of $27.90 \mu \mathrm{m}^{2} / \mathrm{hr}$ as opposed to the CVD mullite coated SiC which exhibited virtually no corrosion.

\section{Acknowledgments}

Research sponsored by the U.S.Department of Energy, Office of Fossil Energy, Advanced Research and Technology Development Materials Program, [DOE/FE AA 151010 0, Work Breakdown Structure Element BU-2], and by the U.S. Department of Energy, Assistant Secretary for Energy Efficiency and Renewable Energy, Office of Transportation Technologies, Ceramic Technology Project of the Propulsion System Materials Program under contract number DE-AC05-96OR22464 with Lockheed Martin Energy Research Corp.

\section{References}

[1] Coal and Synfuels Technology Report, February 7, 1994, Pasha Publications, Arlington, VA, (1994)

[2] Clean-Coal/Synfuels Letter, May 17,1993, McGraw-Hill, New York, (1993)

[3] US DoE, Assistant Secretary for Energy Efficiency and Renewable Energy, Office of Transportation Technology Ceramic Technology Project of the Materials Program, and Fossil Energy AR\&TD Materials Program under contract DE-AC05-840R21400 with Martin Marietta Energy Systems, Inc.

[4] M.K. Ferber, V.J. Tennery, "Behavior of Tubular Ceramic Heat Exchanger Materials in Acidic Coal Ash from Coal-Oil-Mixture Combustion," Ceramic Bulletin 62(2), pp. 236-43, (1983)

[5] D.J.Seery, et.al., pp.356-63 in Proceedings from the Ninth Annual Coal Preparation, Utilization and Environmental Control Contractors Conference Pittsburgh, PA, 1993. U.S. Department of Energy Pittsburgh Technology Center, Pittsburgh, PA, (1993)

[6] N.S. Jacobson and J.L. Smialek, J.Am.Ceram.Soc., 68(8), pp.432-39, (1985)

[7] K. Breder, V.J. Tennery. J.Am.Ceram.Soc., 78(10), pp.2837-40, (1995)

[8] J.I. Federer, J. Materials Engineering, 12, pp.141-149, (1990) 
[9] I.A.Aksay, D.M. Dabbs, and M.Sarikaya, J. Am. Ceram. Soc., 74(10), pp.2343, (1991)

[10] P.F.Becher,J.Am. Ceram. Soc., 74(2), pp.255, (1991)

[11] S. Somiya and Y.Hirata, Am Ceram. Soc. Bull.,70(10) pp.1624, (1991)

[12] R.D.Nixon, S.Chevacharoenkul, R.D.Davis, and T.N.Tiegs, in S. Somiya (ed), Ceramic Transactions, Vol. 6, American Ceramic Society, Westerville, OH, pp. 579, (1990)

[13] J.Schienle and J. Smyth, Final Report, ORNL/Sub/84-47992/1 (1987)

[14] K.Okada and N Otsuka, in S. Somiya (ed),pp. 425, Ceramic Transactions, Vol. 6, American Ceramic Society, Westerville, OH, (1990)

[15] O.Monteiro, Z.Wang, and I.G Brown, J. Mater. Res., 12(9) pp.2401, (1997)

[16] M.L.Auger and V.K.Sarin, Final Report, ORNL/Sub/94-SS110/02 (1997)

[17] R.P. Mulpuri, V.K.Sarin, 19th Annual Cocoa Beach Conference and Exposition on Engineering Ceramics, The American Ceramic Society, Westerville, OH, (1995)

[18] R.P. Mulpuri,V.K.Sarin, J. Mater. Res., 11(6), pp. 1315-24, (1996)

[19] W.A.P. Claasen, J.Bloem, J. Electrochem.Soc., 128(6), pp.1353, (1981)

[20] M.L.Auger and V.K.Sarin, Surface 8 Coatings Tech., 94-95, pp.46-52, (1997)

[21] V.K. Sarin,R.P.Mulpuri U.S. Patent Pending.

[22] Personal Communication John P. Hurley, Energy \& Environmental Research Center, University of North Dakota

[23] T.M.Strobel, J.P.Hurley, K.Breder, J.Holowczak, Proceedings of the 18th Annual Conference on Composites and Advanced Ceramic Materials -A, Cocoa Beach, Fl., Jan. 1994, American Ceramic Society, Westerville, Ohio, (1994)

[24] Wen-Cheng Wei and John W.Halloran, J.Am.Ceram.Soc., 71 [7] 581-87 (1988). 
[25] J.A.Pask,X.W.Zhang and A.P.Tomsia, J.Am.Ceram.Soc., 70[10] pp.704-707 (1987).

[26] M.K. Ferber, V.J. Tennery, Ceramic Bulletin 63(7), pp. 898-904, (1984)

[27] J.A.Bonar, C.R.Kennedy, and R.B.Swaroop, Ceramic Bulletin. 59(4), pp. 473-478, 1980

[28] G.Eriksson, Acta. Chemica Scandanavia, 25(7), pp.2651-2658, (1971)

[29] $\mathrm{F}^{*} \mathrm{~A}^{*} \mathrm{C}^{*}$ Tver2.1, C.W.Bale, A.D.Pelton, W.T.Thompson, Ecole Polytechnique de Montreal/Royal Military College, Canada, (July 1996)

[30] D.Doppalapudi, S.N. Basu, Material. Science and Engineering, A231, pp. 48-54, (1997)

[31] F.F. Abraham, Homogenous Nucleation Theory, The Pretransition Theory of Vapor Condensation, Academic Press, New York and London, (1974)

[32] D.Michel, L.Mazerolles, R.Portier, pp. 435-448, Ceramic Transactions, Vol. 6, American Ceramic Society, Westerville, $\mathrm{OH},(1990)$

[33] Jae-Gon Kim, et.al., Thin Solid Films, 97, pp. 97-106 (1982)

[34] V.K.Sarin, M.L.Auger, pp.33, in Proceedings of the XI Annual Conference on Conference on Fossil Energy Materials, Fossil Energy AR\&TD Materials Program, ORNL (1997)

[35] W.Steinmaier, J.Bloem, J.Electrochem. Soc. 111(2) pp206-209, (1964)

[36] J.N. Lindstrom, K.G. Strenberg, pp. 169-182, in Proceeding 3rd European Conf. CVD, Edited by J.O.Carlsson and J.Lindstrom, Uppsala, Sweden, (1985)

[37] N.Birkis and G.H.Meier, Introduction to High Temperature Oxidation of Metals, Edward Arnold, (1983)

[38] K.Breder, J.Holowczak, J.P.Hurley, and T.M.Strobel, Proceedings of the 19th Annual Conference on Composites and Advanced Ceramic Materials -A," American Ceramic Society, Westerville, Ohio, Cocoa Beach, Fl., Jan. 1995.

[39] W.G.Moffatt, The Handbook of Binary Phase Diagrams, Genium Publishing Corp., Schenectady, NY (1984). 
[40] G.J.Yurek, pp.271-99, in Proceedings of the Conference on Corrosion Erosion of Coal-Conversion Systems Materials, Ed. A.V.Levy.(Jan24-25, 1979) Berkeley, CA, (1979) 
3M COMPANY

Ceramic Materials Department

201-4N-01 3M Center,

St. Paul, MN 55144

M. A. Leitheiser

\section{ARGONNE NATIONAL LABORATORY}

9700 S. Cass Avenue

Argonne, IL 60439

W. A. Ellingson

\section{BABCOCK \& WILCOX}

Domestic Fossil Operations

20 South Van Buren Avenue

Barberton, OH 44023

M. Gold

\section{BETHLEHEM STEEL CORPORATION}

Homer Research Laboratory

Bethlehem, PA 18016

B. L. Bramfitt

J. M. Chilton

\section{BOSTON UNIVERSITY}

Manufacturing Engineering

44 Cummington Street

Boston, MA 02215

V. Sarin

\section{BRITISH COAL CORPORATION}

Coal Technology Development Division

Stoke Orchard, Cheltenham

Glocestershire, England GL52 4ZG

J. Oakey

\section{CANADA CENTER FOR MINERAL \& ENERGY} TECHNOLOGY

568 Booth Street

Ottawa, Ontario

Canada K1A OG1

R. Winston Revie

Mahi Sahoo

\section{DOE}

DOE OAK RIDGE OPERATIONS

P. O. Box 2008

Building 4500N, MS 6269

Oak Ridge, TN 37831

M. H. Rawlins
DOE

DOE OAK RIDGE OPERATIONS

P. O. Box 2001

Oak Ridge, TN 37831

Assistant Manager for

Energy Research and Development

DOE

Federal Energy Technology Center 3610 Collins Ferry Road

P.O. Box 880

Morgantown, WV 26507-0880

D. C. Cicero

F. W. Crouse, Jr.

R. A. Dennis

N. T. Holcombe

W. J. Huber

T. J. McMahon

J. E. Notestein

DOE

Federal Energy Technology Center 626 Cochrans Mill Road

P.O. Box 10940

Pittsburgh, PA 15236-0940
A. L. Baldwin
G. V. McGurl
U. Rao
L. A. Ruth
T. M. Torkos

DOE

OFFICE OF FOSSIL ENERGY

FE-72

19901 Germantown Road

Germantown, MD 20874-1290

F. M. Glaser

DOE

OFFICE OF BASIC ENERGY SCIENCES

Materials Sciences Division

ER-131 GTN

Washington, DC 20545

H. M. Kerch 
ELECTRIC POWER RESEARCH INSTITUTE

P.O. Box 10412

3412 Hillview Avenue

Palo Alto, CA 94303

W. T. Bakker

J. Stringer

\section{EUROPEAN COMMUNITIES JOINT RESEARCH}

CENTRE

Petten Establishment

P.O. Box 2

1755 ZG Petten

The Netherlands

M. Van de Voorde

GEORGIA INSTITUTE OF TECHNOLOGY

Materials Science \& Engineering (0245)

Bunger-Henry Building, Room 276

Atlanta, GA 30332-0245

T. L. Starr

IDAHO NATIONAL ENGINEERING \&

ENVIRONMENTAL LABORATORY

P. O. Box 1625

Idaho Falls, ID 83415

B. H. Rabin

LAWRENCE BERKELEY NATIONAL LABORATORY

University of California

Berkeley, CA 94720

Ian Brown

NATIONAL MATERIALS ADVISORY BOARD

National Research Council

2101 Constitution Avenue

Washington, DC 20418

K. M. Zwilsky

OAK RIDGE NATIONAL LABORATORY

P.O. Box 2008

Oak Ridge, TN 37831

T. M. Besmann

P. T. Carlson

J. M. Crigger (4 copies)

R. R. Judkins

R. A. Lowden

D. P. Stinton

P. F. Tortorelli

I. G. Wright
PACIFIC NORTHWEST NATIONAL

LABORATORY

P. O. Box 999, K3-59

Battelle Boulevard

Richland, WA 99352

R. N. Johnson

\author{
SHELL DEVELOPMENT COMPANY \\ WTC R-1371 \\ P.O. Box 1380 \\ Houston, TX 77251-1380 \\ W. C. Fort
}

THE JOHNS HOPKINS UNIVERSITY

Materials Science \& Engineering

Maryland Hall

Baltimore, MD 21218

R. E. Green, Jr.

THE NORTON COMPANY

High Performance Ceramics Division

Goddard Road

Northborough, MA 01532-1545

N. Corbin

THE TORRINGTON COMPANY

Advanced Technology Center

59 Field St.

Torrington, CT 06790

W. J. Chmura

UNION CARBIDE CORPORATION

Linde Division

P.O. Box 44

175 East Park Drive

Tonawanda, NY 14151-0044

Harry Cheung

UNITED TECHNOLOGIES RESEARCH CENTER

MS 24, Silver Lane

East Hartford, CT 06108

K. M. Prewo

UNIVERSITY OF TENNESSEE

Dept of Materials Science and Engineering Knoxville, TN 37996-2200

P. K. Liaw 
VIRGINIA POLYTECHNIC INSTITUTE \& STATE UNIVERSITY

Department of Materials Engineering

Blackburg, VA 24601

K. L. Reifsnider 